\title{
Characterization of VPS34, a Gene Required for Vacuolar Protein Sorting and Vacuole Segregation in Saccharomyces cerevisiae $\dagger$
}

\author{
PAUL K. HERMAN AND SCOTT D. EMR* \\ Division of Biology, California Institute of Technology, Pasadena, California 91125
}

Received 17 July 1990/Accepted 17 September 1990

\begin{abstract}
VPS34 gene function is required for the efficient localization of a variety of vacuolar proteins. We have cloned and sequenced the wild-type VPS34 gene in order to gain a better understanding of the role of its protein product in this intracellular sorting pathway. Interestingly, disruption of the VPS34 locus resulted in a temperature-sensitive growth defect, indicating that the VPS34 gene is essential for vegetative growth only at elevated growth temperatures. As with the original vps34 alleles, vps34 null mutants exhibited severe vacuolar protein sorting defects and possessed a morphologically normal vacuolar structure. The VPS34 gene VNA sequence identifies an open reading frame that could encode a hydrophilic protein of 875 amino acids. The predicted protein sequence lacks any apparent signal sequence or membrane-spanning domains, su'sgesting that Vps34p does not enter the secretory pathway. Results from immunoprecipitation experiments with antiserum prepared against a TrpE-Vps34 fusion protein were consistent with this prediction: a rare, unglycosylated protein of $\sim 95,000$ Da was detected in extracts of wild-type Saccharomyces cerevisiae cells. Cell fractionation studies indicated that a significant portion of the $V p s 34$ is found associated with a particulate fraction of yeast cells. This particulate Vps34p was readily solubilized by treatment with $2 \mathrm{M}$ urea but not with Triton X-100, suggesting that the presence of Vps34p in this pelletable structure is mediated by protein-protein interactions. vps34 mutant cells also exhibited a defect in the normal partitioning of the vacuolar compartment between mother and daughter cells during cell division. In more than $80 \%$ of the $\Delta v p s 34$ dividing cells examined, no vacuolar structures were observed in the newly emerging bud, whereas in wild-type dividing cells, more than $95 \%$ of the buds had a detectable vacuolar compartment. Our results suggest that the Vps34p may act as a component of a relatively large intracellular structure that functions to facilitate specific steps of the vacuolar protein delivery and inheritance pathways.
\end{abstract}

In eucaryotic cells, the secretory pathway is responsible for the modification and delivery of proteins to a wide variety of intracellular and extracellular compartments. Entry into this pathway is mediated by the presence of an amino-terminal signal sequence and results in translocation across the endoplasmic reticulum (ER) membrane. Proteins destined for secretion are subsequently delivered from the ER to the Golgi complex and then from the Golgi complex to the cell surface via specific membrane-enclosed transport vesicles. This interorganellar flow of proteins from the ER to the cell surface appears to occur by a default mechanism; proteins that lack an intracellular "address" are passively carried to the cell surface (32). However, proteins resident within the ER, Golgi, or lysosomal compartment are characterized by the presence of specific retention or sorting signals which are responsible for their accurate subcellular localizations $(22,32)$. Therefore, mechanisms must exist to allow the cell to recognize and distinguish these various sorting signals and to ultimately deliver the marked proteins to their appropriate intracellular compartments.

Genetic and biochemical studies of protein secretion in the yeast Saccharomyces cerevisiae have demonstrated that many of the essential features of the secretory pathway have been conserved in all eucaryotes, from yeasts to mammals $(28,29)$. In particular, the delivery of proteins to the yeast cell surface also appears to proceed through the ER and Golgi compartments by a bulk flow, or default, mechanism. As with mammalian lysosomal enzymes, proteins destined

\footnotetext{
* Corresponding author.

$\dagger$ Dedicated to the memory of E. W. Herman.
}

for the yeast lysosome-like vacuole depend on the presence of additional sorting information $(15,19,20,52)$. Genetic studies indicate that vacuolar proteins transit through the early stages of the secretory pathway together with proteins destined for secretion or assembly into the plasma membrane $(15,48,52)$. Within the Golgi compartment, the vacuolar proteins are segregated away from proteins destined for secretion and targeted to the yeast vacuole.

In an attempt to identify cellular components involved in the specific segregation, packaging, and delivery of proteins to the vacuole, we used a gene fusion-based selection scheme to isolate a large number of yeast mutants defective in vacuolar protein localization or processing $(2,36)$. More than $600 v p t$ (for vacuolar protein targeting defective) mutants have been isolated, and the recessive mutations have been assigned to at least 33 complementation groups. The $v p t$ mutations have been demonstrated to affect the intracellular sorting of a variety of vacuolar proteins, including the soluble hydrolases carboxypeptidase Y (CPY), proteinase $A(\operatorname{Pr} A)$, and proteinase $B(\operatorname{PrB})$, and an integral membrane protein, repressible alkaline phosphatase $(2,20,36)$. In addition to the observed sorting defects, analysis by both light and electron microscopy techniques has demonstrated that several of the $v p t$ mutants possess morphologically abnormal vacuolar structures (3). These observations have allowed us to assign the vpt mutants to three distinct classes based on their vacuole morphology. The majority of mutants, class A, possess one to three large vacuoles per cell, similar to what is seen in wild-type cells. In other vpt complementation groups, the cells are characterized either by the presence of multiple, small vacuolelike organelles (class B mutants) or by the apparent lack of any normal 
TABLE 1. Strains used

\begin{tabular}{|c|c|c|}
\hline Strain & Genotype & $\begin{array}{l}\text { Reference } \\
\text { or source }\end{array}$ \\
\hline \multicolumn{3}{|l|}{ S. cerevisiae } \\
\hline SEY6210 & MAT $\alpha$ leu2-3,112 ura3-52 his3- $\Delta 200$ trpl- $\Delta 901$ lys2-801 suc2- $\Delta 9$ & 36 \\
\hline SEY6211 & MATa leu2-3,112 ura3-52 his3- $\Delta 200$ trpl- $\Delta 901$ ade2-101 suc2- $\Delta 9$ & 36 \\
\hline SEY34-2 & SEY6210 vps $34-2$ & 36 \\
\hline SEY34-6 & SEY6211 vps34-6 & 36 \\
\hline PHY102 & SEY6210 vps $34 \Delta 1:: T R P 1$ & This study \\
\hline PHY103 & SEY6211 vps34 $1:: T R P 1$ & This study \\
\hline DKY6224 & MATa, leu2-3,112 ura3-52 his3- $\Delta 200$ trpl- $\Delta 901$ ade2-101 suc2- $\Delta 9$ $\Delta p e p 4:: L E U 2$ & 19 \\
\hline SEY6210.5 & 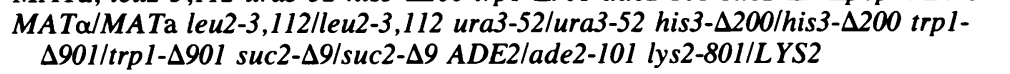 & This study \\
\hline PHY120 & 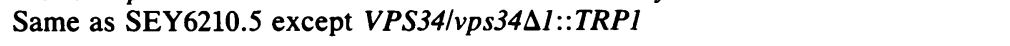 & This study \\
\hline \multicolumn{3}{|l|}{ E. coli } \\
\hline MC1061 & $\mathrm{F}^{-} h s d R$ hsdM ${ }^{+}$araD139 (araABOIC-leu)7679 (lac)X74 galU galK rpsL & $5 a$ \\
\hline JM101 & $\mathrm{F}^{\prime}$ traD36 lacI ${ }^{9} \Delta \mathrm{M} 15$ proAB $\Delta$ lac(lac-pro) supE thi & 27 \\
\hline
\end{tabular}

vacuolar structures (class $C$ mutants). In addition to the $v p t$ mutants, two other sets of mutants (pep and $v p l$ ) that affect vacuolar protein localization or processing have been described $(16,21,38,40)$. The $v p l$ mutants were also identified by selecting for mutants defective in vacuolar protein localization $(38,40)$. Genetic analysis has demonstrated that significant overlap exists between the VPT and VPL complementation groups, and the $v p t$ and $v p l$ mutants are now collectively referred to as $v p s$, for vacuolar protein sorting defective $(36,38)$. The pep mutants were originally identified in genetic screens for yeast mutants exhibiting decreased levels of CPY activity (16), and subsequent analysis has shown that most of the pep mutants also exhibit vacuolar protein sorting defects (38). In all, the mutants in these different collections define more than 47 complementation groups which appear to be required for the delivery of soluble vacuolar hydrolases such as CPY (21). These initial genetic studies, therefore, indicate that vacuolar protein delivery is a complex process that involves the direct or indirect participation of a relatively large number of gene functions. To functionally dissect this pathway and gain an understanding of the underlying molecular mechanisms, we have initiated efforts to clone specific VPS genes and to characterize their respective gene products.

Eight independent mutant alleles of the VPS34 locus were originally isolated in a genetic selection for yeast vacuolar protein targeting mutants (36). vps34 mutant cells were observed to exhibit severe defects in the sorting of the soluble vacuolar hydrolases, CPY, $\operatorname{PrA}$, and $\operatorname{PrB}$. However, light microscopy analyses revealed that vps 34 cells contain morphologically normal vacuoles (class A; 3 ). This latter observation indicated that vps34 cells are competent for vacuole assembly; in combination, these observations suggested that the wild-type VPS34 gene product might be specifically involved in the intracellular sorting and delivery of soluble vacuolar proteins. However, an electron microscopy analysis of vps 34 mutants has demonstrated that in addition to a morphologically normal vacuole, vps34 cells accumulate a variety of abnormal membranous structures within their cytoplasm, including Berkeley bodies and 80-nm vesicles (3). Similar membrane-enclosed material was also observed in class $\mathrm{C}$ vps mutants, which lack a detectable normal vacuolar compartment. vps34 cells have several other phenotypes in common with the class $\mathrm{C} v p s$ mutants, including sensitivity to osmotic stress and extreme temperature-sensitive growth defects $(3,36)$. This phenotypic sim- ilarity to yeast mutants that are defective in the assembly of the vacuolar compartment might also suggest a role for the VPS34 gene product in vacuole biogenesis.

Toward a better understanding of the role of the VPS34 gene product in vacuolar protein sorting and biogenesis, we report here on the cloning and sequencing of the VPS34 gene, the phenotypic consequences of a VPS34 null allele ( $\Delta v p s 34)$, and the identification and localization of the $V P S 34$ gene product. Our results suggest that Vps34p is a relatively rare yeast polypeptide that may function as a component of a large intracellular multiprotein structure to facilitate vacuolar protein delivery.

\section{MATERIALS AND METHODS}

Strains and media. The $S$. cerevisiae and Escherichia coli strains used are listed in Table 1 . The yeast strains were constructed by standard genetic techniques (46). Standard yeast (46) and $E$. coli (27) media were used and supplemented as needed.

Reagents. DNA restriction and modifying enzymes were from either New England BioLabs, Inc. (Beverley, Mass.), or Boehringer Mannheim Biochemicals (Indianapolis, Ind.). Zymolyase-100T (Kirin Brewery Co.) was obtained from Seikagako Kogyo Co. (Tokyo, Japan), lyticase was from Enzogenetics, and 5-bromo-4-chloro-3-indoyl- $\beta$-D-galactoside (X-Gal), phenylmethanesulfonyl fluoride, and isopropyl- $\beta$-D-thiogalactopyranoside (IPTG) were from Boehringer Mannheim Biochemicals. Tran ${ }^{35} \mathrm{~S}$ label was from ICN Radiochemicals (Irvine, Calif.), $\left[\alpha-{ }^{32} \mathrm{P}\right] \mathrm{CTP}$ and $\left[\alpha-{ }^{35} \mathrm{~S}\right]$ dATP were from Amersham (Arlington Heights, Ill.), Autofluor was from Dupont, NEN Research Products (Boston, Mass.), 5(6)-carboxy-2'-7'-dichlorofluorescein diacetate (CDCFDA) was from Molecular Probes, Inc. (Eugene, Ore.), and RNasin was from Promega Biotec (Madison, Wis.). Sequenase enzyme and the Sequenase DNA sequencing kit were from United States Biochemicals (Cleveland, Ohio), the T3/T7 RNA transcription kit was from Stratagene (La Jolla, Calif.), and the polymerase chain reaction (PCR) Gene Amp DNA amplification kit was from Perkin Elmer Cetus (Norwalk, Conn.). All other chemicals were purchased from Sigma Chemical Co. (St. Louis, Mo.). Antiserum to phosphoglycerokinase was a gift from Jeremy Thorner, and the antiserum to CPY was described previously (19).

Recombinant DNA methods and plasmid constructions. All 
recombinant DNA manipulations were done as previously described (25).

The yeast $E$. coli shuttle vector, pPHYC18, was constructed from pSEYC68 in two steps. pSEYC68 is a derivative of plasmid pSEYC58 (11) in which the pUC8 polylinker sequences have been replaced with those of pUC18. First, pSEYC68 DNA was digested with XhoI and HpaI, and the $X$ hoI 3 '-recessed ends were filled in with Klenow polymerase. These two blunt ends were subsequently ligated to remove $\sim 600$ bp from the CEN4 region of pSEYC68. This deletion removed the only KpnI site in pSEYC68 and did not affect the mitotic stability of the resultant yeast plasmid, pPHYC16 (data not shown; see reference 26). The polylinker sequences of pPHYC16 were then replaced with the polylinker from pBluescript $\mathrm{KS}(+)$ (pBP; Stratagene) by replacing the $\sim 400$-bp PvuII fragment of pPHYC16 with that from the pBP plasmid to yield pPHYC18. The $\sim 5.0-\mathrm{kb}$ ClaI-SacI fragment of pPHY34 was subcloned into pBP $(\mathrm{KS}+)$ to yield plasmid pPHY46. This VPS34-containing fragment was then removed as a SalI-SacI fragment and subcloned into pSEY18 (a derivative of pSEY8 with pUC18 polylinker sequences; 11) to make pPHY52, a multicopy VPS34 plasmid.

The yeast integrating vector, pPHYI10, was constructed by inserting the $\sim 800$-bp EcoRI-Pst I fragment of YRp7, which contains the yeast TRPI gene (51), into the NdeI site of pUC18. All restriction enzyme ends were filled in or digested with Klenow polymerase to create blunt ends. This plasmid contains a yeast selectable marker, TRPI, but no yeast origin of replication.

Plasmid pPHY40 was used to construct exonuclease IIImung bean nuclease deletions of VPS34 sequences in an attempt to define the minimum complementing fragment and was constructed as follows. The original YCp50 complementing plasmid, pPHY34, was digested with KpnI, and the 3 ' overhang ends were removed by treatment with mung bean nuclease. The plasmid was then digested with $C l a I$, and this 4.1-kb ClaI-KpnI (blunt) fragment was subcloned into ClaI-SmaI-digested pPHYC18 to yield pPHY40. Plasmids pPHY42 and pPHY43 were constructed by subcloning the VPS34 locus, as a $\sim 4.1-\mathrm{kb} K p n I-S a c I$ fragment from pPHY 40, into pBP (-) and pBP (+), respectively (both pBP plasmids were of the KS series).

The integrative mapping plasmid, pPHY35, was constructed by cloning the 3.4-kb BamHI-SacI fragment of pPHY34 into the pPHYI10 vector. Plasmid pPHY38 was used to make a gene disruption of the VPS34 locus and was constructed in multiple steps, as follows. First, the $4.1-\mathrm{kb}$ ClaI-KpnI fragment of pPHY34 was subcloned into the pPHYC18 yeast vector. This VPS34-containing DNA fragment was subsequently removed as a Pst $\mathrm{I}-K p n \mathrm{I}$ fragment and subcloned into pUC18, to construct pPHY36. pPHY36 was digested with $X h o I$, the XhoI 3 '-recessed ends were filled in, and the plasmid was then cut with BamHI. The yeast TRPI gene was subcloned into this plasmid as an EcoRI (blunt)-BglII fragment from YRp7, where the EcoRI 3 '-recessed ends were filled in with Klenow polymerase. Plasmid pPHY34.17 was made by cloning the $1.0-\mathrm{kb}$ Bam HIXhoI fragment of pPHY34 into pPHYC18.

Northern (RNA) analysis. Yeast RNA was prepared as previously described (10). $\operatorname{Poly}(\mathrm{A})^{+}$RNA was isolated by binding total yeast to oligo(dT)-cellulose in the presence of $0.5 \mathrm{M} \mathrm{LiCl}$, extensive washing with the high-salt buffer, and then batch elution with $10 \mathrm{mM}$ Tris hydrochloride ( $\mathrm{pH} 7.5)-1$ mM EDTA. The RNA was subsequently electrophoresed on formaldehyde-1\% agarose gels and transferred to Gene-
Screen membranes (1). Single-stranded $\left[{ }^{32} \mathrm{P}\right] \mathrm{RNA}$ probes were prepared by transcription from pPHY34.17 with either T3 or T7 RNA polymerase and were hybridized to the RNA blot as described previously (1).

Yeast genetics. Standard yeast genetics techniques were used throughout (46). Yeast transformation was achieved by the method of alkali cation treatment (14), and transformants were selected on SD medium.

The VPS34 gene was cloned by complementing the severe temperature-sensitive growth defect associated with the vps34-2 allele. SEY34-2 cells (vps34-2 ura3-52) were transformed with a yeast genomic DNA library constructed in plasmid YCp50 (37), and $\mathrm{Ura}^{+}$transformants were selected at $26^{\circ} \mathrm{C}$. Transformant colonies were subsequently replicated to $37^{\circ} \mathrm{C}$ YPD plates, and plasmids conferring a temperatureresistant phenotype upon the cells were isolated and analyzed. Plasmid DNA was isolated from yeast cells by resuspension of a moderately large colony in $0.2 \mathrm{ml}$ of $10 \mathrm{mM}$ Tris hydrochloride ( $\mathrm{pH} 7.5$ )-1 mM EDTA and extraction two times with a 50:50 phenol-chloroform mixture. The DNA was precipitated from the aqueous phase and used to transform competent $E$. coli cells to ampicillin resistance.

To construct a gene disruption of the VPS34 locus, the 2.7-kb HindIII-KpnI fragment of pPHY38 was gel isolated (from a partial digestion) and used to transform the diploid yeast strain, SEY6210.5, and the haploid strains, SEY6210 and SEY6211, to tryptophan prototrophy. For integrative mapping, plasmid pPHY35 was digested with XhoI and transformed into SEY6211. Trp ${ }^{+}$transformants were selected and subsequently crossed to the yeast strain SEY34-2 for genetic analysis.

PCR analysis of yeast genomic DNA. Approximately 0.2 $\mathrm{OD}_{600}$ (optical density at $600 \mathrm{~nm}$ ) equivalents of a yeast culture were pelleted and resuspended in $200 \mu \mathrm{l}$ of $\mathrm{H}_{2} \mathrm{O}$. Glass beads $(0.55 \mathrm{~mm})$ were added, and the cells were broken by vigorous vortexing for $60 \mathrm{~s}$. The lysates were centrifuged for 2 min at $13,000 \times g$ to remove cell debris, and $10 \mu \mathrm{l}$ of this cleared lysate was used as the genomic DNA template. The PCR reactions were performed as described in the Perkin Elmer Cetus Gene Amp DNA amplification kit. The nucleotide sequences of the primers are as follows: 1, ATAACATCTCCGTGAAGCATTGAGG; 2, TACGTGAT TAAGCACACAAAGGCAG; and 3, TTTAATGTCCGGC TTCACTTGCTTG $\left(5^{\prime}\right.$ to $\left.3^{\prime}\right)$. Before addition of the TaqI polymerase, the reaction mixes were heated to $94^{\circ} \mathrm{C}$ for 10 min. TaqI enzyme was added, and 30 cycles of amplification were carried out, with the typical cycle consisting of $2 \mathrm{~min}$ at $55^{\circ} \mathrm{C}$ (annealing), $3 \mathrm{~min}$ at $72^{\circ} \mathrm{C}$ (extension), and $1 \mathrm{~min}$ at $94^{\circ} \mathrm{C}$ (denaturation). The reaction products were analyzed on $1.2 \%$ agarose gels stained with ethidium bromide. Since these PCR primers are contained within the transforming DNA fragment, we analyzed the genomic DNA from haploid progeny of independent PHY120 meioses to ensure that integration had occurred at the VPS34 locus. We have also disrupted the VPS34 gene with the 2.1-kb Alw NI fragment of pPHY38 (primer 1 is upstream of the 5 '-most $A l w$ NI site) and have obtained identical results in the subsequent PCR analysis.

Preparation of antisera against Vps34p. A gene fusion between $E$. coli trpE gene and VPS34 was constructed by using the pATH vector system (8). We subcloned the $1.0-\mathrm{kb}$ $X b a I-X h o I$ fragment of pPHY34 into XbaI-SalI-digested pATH2 DNA to produce plasmid pPHY51.1, which encodes a TrpE-Vps34p fusion protein containing 338 amino acids of Vps34p. This TrpE fusion protein was induced and prepared as previously described (18) except that $2 \%$ Triton X-100 
was used instead of $0.2 \%$ Nonidet P-40. Protein induction was examined by analyzing whole-cell lysates on sodium dodecyl sulfate (SDS)-polyacrylamide gels stained with Coomassie blue. A large-scale preparation of the fusion protein was electrophoresed and eluted from a $9 \%$ preparative SDS-polyacrylamide gel. The protein eluant was mixed with Freund adjuvant and injected into New Zealand White male rabbits $(\sim 150 \mu \mathrm{g}$ per rabbit). Antiserum was collected after multiple secondary injections.

DNA sequencing and sequence analysis. Exonuclease IIImung bean nuclease deletions were performed on plasmids pPHY42 and pPHY43 as described in the Stratagene Bluescript manual except that following nuclease digestion the treated DNA was eluted from a $1 \%$ agarose gel. Singlestranded phagemid DNA was purified following M13 superinfection, and the single-stranded DNA templates were sequenced by using standard dideoxy-chain termination techniques (44).

The predicted protein sequence of $\mathrm{Vps} 34 \mathrm{p}$ was compared with the contents of the National Biomedical Research Foundation (NBRF) protein data base (release 21.0, June 1989) with the FASTA program and the contents of the GenBank data base (release 60.0, June 1989) with the TFASTA program (31). The comparisons were performed with the University of Wisconsin Genetics Computer Group sequence analysis package for VAX/VMS computers (6).

Cell labeling and immunoprecipitation. Immunoprecipitations from whole cells were performed as previously described (19), with the following modifications. Yeast cells were grown to mid-logarithmic phase in yeast nitrogen base (YNB) minimal medium supplemented with the appropriate amino acids. Two units of cells at an $\mathrm{OD}_{600}$ of 1.0 was centrifuged and resuspended in $0.5 \mathrm{ml}$ of the same medium. Bovine serum albumin (final concentration, $1 \mathrm{mg} / \mathrm{ml}$ ) and 150 $\mu \mathrm{Ci}$ of Tran ${ }^{35} \mathrm{~S}$ label were added to this culture, and the cells were incubated for 20 to $30 \mathrm{~min}$ at the appropriate temperature. A chase, if necessary, was initiated by adding cold methionine to a final concentration of $2 \mathrm{mM}$. The labeling or chase reaction was terminated by the addition of trichloroacetic acid (TCA) to a final concentration of $5 \%$. The remaining steps were as described (19) except that only two immunoprecipitation washes were performed, one with IP buffer $(0.5 \%$ Tween $20,50 \mathrm{mM}$ Tris hydrochloride [pH 7.5], $150 \mathrm{mM} \mathrm{NaCl}, 0.1 \mathrm{mM}$ EDTA) and one with IP buffer 2 (50 $\mathrm{mM}$ Tris hydrochloride [pH 7.5], $150 \mathrm{mM} \mathrm{NaCl}, 0.1 \mathrm{mM}$ EDTA). The samples were electrophoresed on $8 \%$ SDSpolyacrylamide gels. To assess $\mathrm{N}$-linked oligosaccharide modification, the cells were incubated in the presence of tunicamycin $(20 \mu \mathrm{g} / \mathrm{ml})$ for $15 \mathrm{~min}$ prior to labeling. The CPY fractionation immunoprecipitations were done as previously described (36).

Fractionation of Vps34p. Strain DKY6224 (spep4) harboring plasmid pPHY52 was grown at $30^{\circ} \mathrm{C}$ to an $\mathrm{OD}_{600}$ of $\sim 0.7$ in YNB-glucose minimal medium. Cells were pelleted and incubated with $100 \mathrm{mM}$ Tris-sulfate ( $\mathrm{pH} \mathrm{9.4)-10} \mathrm{mM} \mathrm{dithio-}$ threitol for $15 \mathrm{~min}$ at $30^{\circ} \mathrm{C}$. The cells were pelleted and resuspended in YNB-glucose medium ( $\mathrm{pH}$ 7.5) supplemented with $1.3 \mathrm{M}$ sorbitol. Oxylyticase was added to $40 \mathrm{U}$ per $\mathrm{OD}_{600}$ equivalent, and the cells were spheroplasted for $20 \mathrm{~min}$ at $30^{\circ} \mathrm{C}$. The spheroplasts were pelleted and labeled in YNB-glucose-1.3 M sorbitol medium with Trans ${ }^{35} \mathrm{~S}$ label $(300 \mu \mathrm{Ci} / \mathrm{ml})$ for $30 \mathrm{~min}$ at $30^{\circ} \mathrm{C}$. $\mathrm{NaF}$ and $\mathrm{NaN}_{3}$ were added to $10 \mathrm{mM}$, and the cultures were immediately put on ice. The labeled spheroplasts were gently pelleted at $2,000 \times g$ and then resuspended in $1.2 \mathrm{M}$ sorbitol-100 mM Tris hydrochloride ( $\mathrm{pH}$ 7.5)-10 mM EDTA containing phenylmethylsulfo- nyl fluoride $(1 \mathrm{mg} / \mathrm{ml})$, leupeptin $(50 \mu \mathrm{g} / \mathrm{ml})$, and pepstatin A $(14 \mu \mathrm{g} / \mathrm{ml})$. The cells were osmotically lysed by the rapid addition of 10 volumes of lysis buffer $(0.25 \mathrm{M}$ sucrose, 100 $\mathrm{mM}$ Tris hydrochloride [pH 7.5], $10 \mathrm{mM}$ EDTA, $1 \mathrm{mg}$ of bovine serum albumin per $\mathrm{ml} ; 10$ ). The unlysed cells were removed by centrifugation at $500 \times g$ for $2 \mathrm{~min}$. The resulting supernatant was separated into four equal aliquots, and $\mathbf{0 . 2}$ volume of one of the following was added: distilled water, $5 \%$ Triton $\mathrm{X}-100,10 \mathrm{M}$ urea, or $5 \mathrm{M} \mathrm{NaCl}$. The lysate solutions were incubated at $0^{\circ} \mathrm{C}$ for $10 \mathrm{~min}$ and then centrifuged at $100,000 \times g$ for $30 \mathrm{~min}$ in a $70.1 \mathrm{Ti}$ rotor $($ Beckman Instruments, Inc.). The supernatant was carefully removed and made $6 \%$ in TCA, and the centrifugation pellet was resuspended in $6 \%$ TCA. Both TCA precipitations were held on ice for $20 \mathrm{~min}$ and then centrifuged at $13,000 \times g$ for 2 min. The TCA pellets were washed twice with acetone, dried, and resuspended in $150 \mu$ l of boiling buffer $(50 \mathrm{mM}$ Tris hydrochloride [pH 7.5], $1 \mathrm{mM}$ EDTA, 1\% SDS). The samples were then immunoprecipitated as described above.

Labeling of cells with fluorescent dyes. Yeast cells were labeled with fluorescein isothiocyanate (FITC) and CDCFDA as previously described $(3,34)$ except that when FITC was used, the cells were washed with solutions containing $2 \%$ glucose. The ade2 endogenous fluorophore was visualized in stationary-phase yeast cells grown either in YPD medium or in adenine-limiting medium, as previously described (53). Microscopy and photography were done as previously described (3).

Nucleotide sequence accession number. The GenBank accession number for the sequence reported is X53531.

\section{RESULTS}

Cloning and characterization of the VPS34 locus. The VPS34 gene was cloned by complementation of the recessive temperature-sensitive growth defect associated with the vps34-2 allele. SEY34-2 cells (vps34-2 ura3-52; Table 1) were transformed with a yeast genomic library constructed in the YCp50 centromere-containing plasmid (37). Approximately $20,000 \mathrm{Ura}^{+}$transformants were selected at $26^{\circ} \mathrm{C}$ on minimal plates lacking uracil. After 3 days at $26^{\circ} \mathrm{C}$, the transformants were replicated onto prewarmed YPD plates and incubated at $37^{\circ} \mathrm{C}$. Temperature-resistant colonies were picked, and the plasmid DNA was isolated. After amplification in $E$. coli, the plasmids were reintroduced into SEY34-2 to retest their complementing activity. Only one plasmid, pPHY34, was able to confer a temperature-resistant phenotype upon the cells (Fig. 1). This plasmid also complements the temperature-sensitive defect associated with the vps34-6 allele (data not shown).

We also tested the ability of pPHY34 to complement the other phenotypes associated with vps 34 mutants. vps 34 cells have previously been shown to be sensitive to osmotic stress (3), as demonstrated by their inability to grow on solid media containing $1.5 \mathrm{M} \mathrm{NaCl}$ (Fig. 1). The cloned DNA was able to fully complement the osmotic sensitivity phenotype of vps34 mutants (Fig. 1).

The cloned DNA was also able to complement the vacuolar protein sorting defects associated with vps34 mutations. We directly analyzed the localization of CPY in yeast cells by labeling intact spheroplasts with $\left[{ }^{35}\right.$ S $]$ methionine and $\left[{ }^{35}\right.$ S $]$ cysteine, fractionating the cultures into supernatant (extracellular) and pellet (intracellular) fractions, and then immunoprecipitating the cultures with antiserum to CPY. The spheroplasts were labeled for $20 \mathrm{~min}$ and then chased for an additional $30 \mathrm{~min}$. In wild-type yeast cells, $>95 \%$ of the 

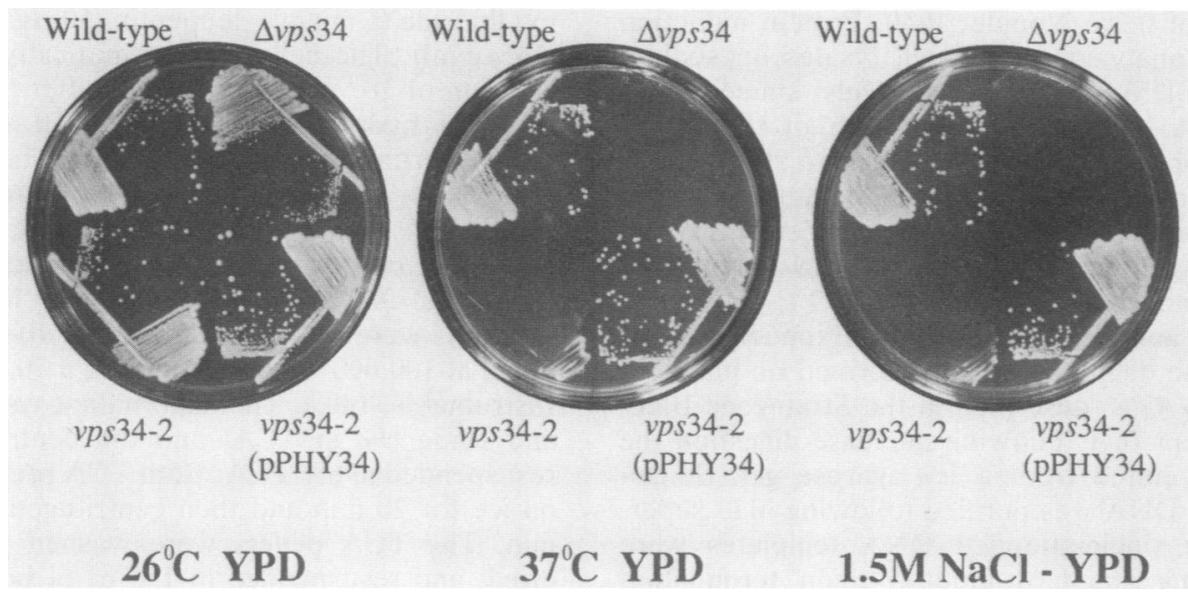

FIG. 1. Ability of plasmid pPHY34 to fully complement the growth defects associated with the vps34-2 allele. The following strains were streaked out onto either $26^{\circ} \mathrm{C}$ YPD, $37^{\circ} \mathrm{C}$ YPD, or $26^{\circ} \mathrm{C}$ YPD-1.5 M NaCl plates and incubated for 2 to 6 days: SEY6210 (wild type), PHY102 (Avps34), SEY34-2 (vps34-2), and SEY34-2 harboring plasmid pPHY34 [vps34-2(pPHY34)].

newly synthesized CPY was present as a $61-\mathrm{kDa}$ mature species in an intracellular fraction (Fig. 2). In contrast, in vps34-2 cells, $<5 \%$ of the CPY was present as a mature species. The majority of the CPY was present as the Golgimodified $69-\mathrm{kDa}(\mathrm{p} 2)$ precursor molecule, and more than $90 \%$ of this p2 CPY was secreted by the mutant cells (similar to results for the $\Delta v p s 34$ mutant in Fig. 2). Therefore, vps34-2 mutants exhibited severe defects in the localization of CPY. The introduction of plasmid pPHY34 into vps34-2 mutants corrected this sorting defect (data not shown; see Fig. 2). The genomic DNA present within plasmid pPHY34 was therefore capable of complementing all vps 34 mutant phenotypes examined.

Restriction enzyme mapping demonstrated that this complementing plasmid, pPHY34, contained a genomic DNA insert of $\sim 8 \mathrm{~kb}$ (Fig. 3A). Various restriction fragments were subcloned into the yeast single-copy vector, pPHYC18, and were subsequently tested for complementing activity (Fig. $3 \mathrm{~A})$. This analysis localized the complementing activity to a 4.1-kb ClaI-KpnI fragment. To more precisely define the limits of the VPS34 functional unit, we performed exonuclease III-mung bean nuclease deletions upon this ClaI-KpnI

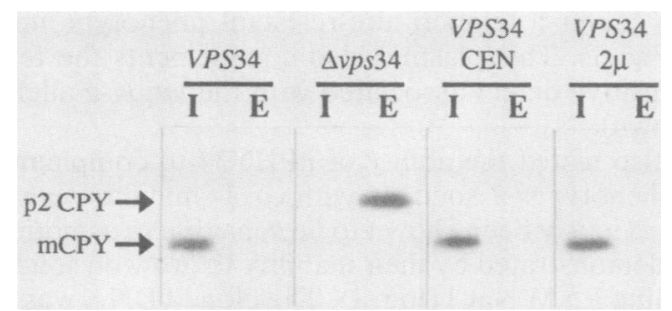

FIG. 2. Intracellular sorting of CPY. Yeast spheroplasts were radiolabeled with Tran ${ }^{35} \mathrm{~S}$ label for $20 \mathrm{~min}$ at $30^{\circ} \mathrm{C}$ and then chased for $30 \mathrm{~min}$ at $30^{\circ} \mathrm{C}$ following the addition of cold methionine and cysteine to $2 \mathrm{mM}$. The labeled cultures were centrifuged for $2 \mathrm{~min}$ at $13,000 \times g$ and separated into a pellet (I, intracellular) and a supernatant (E, external) fraction. The level of CPY in each fraction was assessed by quantitative immunoprecipitation with antiserum to CPY. The strains examined were SEY6210 (VPS34), PHY102 ( $\Delta v p s 34)$, PHY102 harboring the pPHY34 plasmid (VPS34 CEN), and SEY6210 harboring the multicopy VPS34 plasmid pPHY52 $(V P S 342 \mu)$. The positions of mature CPY (mCPY; $61 \mathrm{kDa})$ and $\mathrm{p} 2$ CPY $(69 \mathrm{kDa})$ are indicated. fragment. Deletions of as little as $\mathbf{2 0 0} \mathrm{bp}$ from the $\mathrm{KpnI}$ side resulted in a loss of complementing activity. However, we found that as much as $1,200 \mathrm{bp}$ could be removed from the ClaI side without any detectable loss of function. The final fragment shown in Fig. 3A represents the smallest DNA fragment found to possess VPS34 complementing activity.

To determine whether the pPHY34 complementing activity represented the authentic VPS 34 locus, we assessed the genetic linkage between the cloned genomic DNA and the vps34-2 allele. The 3.4-kb BamHI-SacI fragment of pPHY34 was subcloned into a TRPI yeast integrating plasmid, pPHYI10. The resultant plasmid, pPHY35, was digested with $X h o I$ to direct its integration to the chromosomal homolog of the cloned DNA (41). This digested DNA was transformed into the yeast strain SEY6211, and Trp ${ }^{+}$transformants were selected and mated to SEY34-2. The resultant diploid was induced to sporulate, and the meiotic progeny were analyzed by standard tetrad analysis. If the cloned DNA represented the true VPS34 locus, then the Trp ${ }^{+}$and $\mathrm{Ts}^{+}$phenotypes would be expected to cosegregate. In all 20 tetrads analyzed, a $2 \operatorname{Trp}^{+} \mathrm{Ts}^{+}: 2 \mathrm{Trp}^{-} \mathrm{Ts}^{-}$segregation pattern was observed. These results indicate that the complementing DNA within pPHY34 originated from a region of the yeast genome that is homologous to the VPS34 gene.

RNA transcripts from the VPS34 locus were identified by probing Northern blots of yeast RNA with single-stranded RNA probes prepared from either strand of the VPS34 clone. A single poly $(\mathrm{A})^{+}$RNA of approximately $2,800 \mathrm{nu}-$ cleotides was detected from this locus (Fig. 3B). The direction of transcription was determined to be from the BamHI site toward the XhoI site (Fig. 3).

DNA sequencing and sequence analysis. The VPS34 minimum complementing fragment (Fig. 3A) was sequenced by using standard dideoxy-chain termination methods as described in Materials and Methods. The DNA sequence identifies an open reading frame of $2,625 \mathrm{bp}$ which has the potential to encode a protein of 875 amino acids (Fig. 4A). Upstream of the initiation codon, at position -120 , there is a TATA-like sequence element, TATAT, which closely resembles the consensus TATAAA yeast sequence (Fig. 4A; 49). A sequence, TAGT. . .TAG. . .TTT, which closely approximates the proposed yeast transcription termination consensus signal, was identified 86 nucleotides downstream 


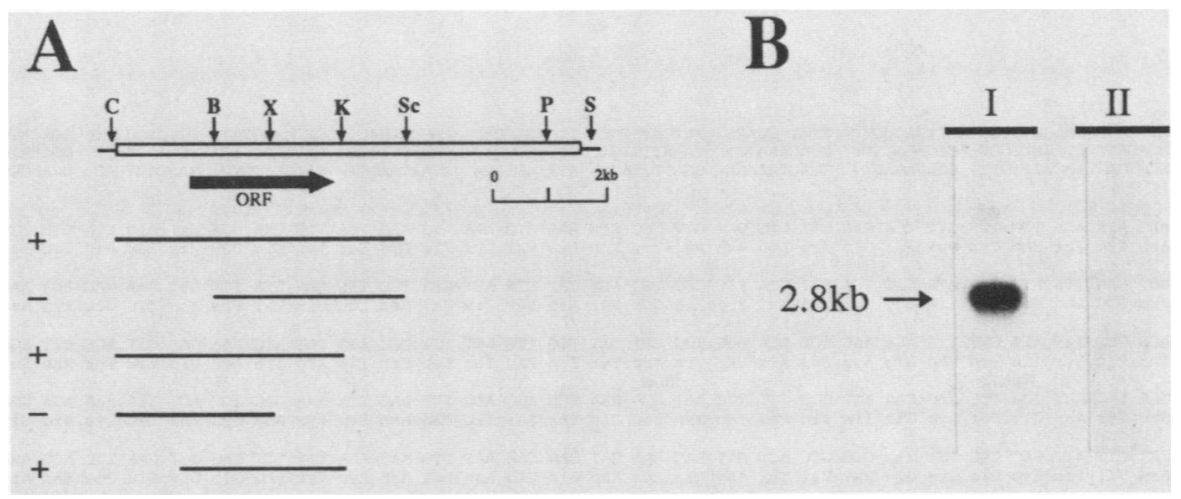

FIG. 3. (A) Restriction enzyme map of the $\sim 8-\mathrm{kb}$ genomic DNA insert in plasmid pPHY34. The VPS34 coding region and direction of transcription are indicated by the heavy arrow. Restriction enzyme abbreviations: ClaI (C), BamHI (B), XhoI (X), KpnI (K), SacI (Sc), PvuII (P), and SalI (S). Specific restriction fragments or exonuclease III-mung bean deletions were subcloned into pPHYC18 and transformed into SEY34-2. A plus sign indicates that the fragment was able to complement the vps34-2 temperature-sensitive growth defect. ORF, open reading frame. (B) Identification of the VPS34 RNA transcript by Northern blot analysis. Poly(A) ${ }^{+}$RNA (5 $\mu$ g) was run out on formaldehyde-1\% agarose gels, transferred to GeneScreen membranes, and probed with antisense (I) or sense (II) VPS34 [ $\left.{ }^{34} \mathrm{P}\right] \mathrm{RNA}$ made with either T7 or T3 RNA polymerase from plasmid pPHY34.17.

from the stop codon (Fig. 4A; 56). The predicted open reading frame is terminated by a single UGA codon, and its size is in good agreement with that of the single $2.8-\mathrm{kb}$ poly $(\mathrm{A})^{+}$RNA detected from this region. The deduced protein sequence indicates that $\mathrm{Vps} 34 \mathrm{p}$ is relatively hydrophilic and possesses 10 potential sites for $\mathrm{N}$-linked glycosyl modification. A hydropathy analysis of this sequence suggests the absence of an N-terminal signal sequence or any potential membrane-spanning domains within this protein (Fig. 4B). A comparison of the predicted protein sequence with those in the GenBank and NBRF data bases failed to reveal any sequence similarities of obvious significance (24, 31).

Deletion-disruption of the VPS34 gene results in a temperature-sensitive growth defect. To examine the phenotypic consequences of a null allele of VPS34, we constructed a gene deletion-disruption of this locus by using plasmid pPHY38. This plasmid contains a copy of the VPS34 gene in which the 1.0-kb BamHI-XhoI fragment has been replaced with the yeast TRPI gene (Fig. 5A). Following linearization, this DNA was used to transform the diploid strain SEY6210.5 to tryptophan prototrophy by replacing one wild-type copy of VPS34 with the disrupted allele through homologous recombination. Two independent $\operatorname{Trp}^{+}$transformants were placed on sporulation medium, and their resultant progeny were subjected to tetrad analysis. In all 19 tetrads examined, the Trp phenotype was observed to segregate $2 \operatorname{Trp}^{+}: 2 \operatorname{Trp}^{-}$, as expected for a single replacement event. As this result implies, all four haploid progeny, including the disrupted (or $\operatorname{Trp}^{+}$) haploid strains, were viable at $26^{\circ} \mathrm{C}$, and therefore $V P S 34$ is not an essential yeast locus. Because we had previously isolated recessive temperaturesensitive alleles of the VPS34 locus (36), we examined the growth of the aforementioned meiotic progeny at $37^{\circ} \mathrm{C}$. We found that all tetrads displayed a $2 \operatorname{Trp}^{+} \mathrm{Ts}^{-}: 2 \operatorname{Trp}^{-} \mathrm{Ts}^{+}$ segregation pattern, indicating that our gene disruption of the VPS34 locus results in a temperature-sensitive growth defect. This finding implies that the VPS34 gene product is essential for growth only at elevated growth temperatures. The construction of a VPS34 gene disruption in the haploid yeast strains SEY6210 and SEY6211 also resulted in a temperature-sensitive growth defect (Fig. 1). The $\Delta v p s 34$ strains were observed to arrest at the one- to two-cell stage following a shift to $37^{\circ} \mathrm{C} . \Delta v p s 34$ cells that had been arrested for $3 \mathrm{~h}$ at $37^{\circ} \mathrm{C}$ did not assume a uniform arrest morphology (data not shown). At $26^{\circ} \mathrm{C}$, the generation time of $\Delta v p s 34$ mutants is approximately 1.5 to 2 times that of an isogenic wild-type strain.

We verified the genomic structure of the vps34 $11:: T R P 1$ alleles with an application of PCR DNA amplification methods $(42,43)$. Yeast cells were lysed with glass beads and centrifuged for $2 \mathrm{~min}$ at $13,000 \times \mathrm{g}$. An aliquot of this clarified lysate corresponding to $0.01 \mathrm{OD}_{600}$ cell equivalents was used for the PCR analysis. Each DNA template was mixed with a set of three 25 -mer oligonucleotide primers that hybridize to specific regions of either the VPS34 gene or the $T R P I$ locus (Fig. 5A). The primers were chosen such that the wild-type VPS34 gene would produce a single PCR product of $900 \mathrm{bp}$ from primers 1 and 2 and the $v p s 34 \Delta 1:: T R P 1$ allele would result in a single 1,100 -bp PCR product from primers 1 and 3 (Fig. 5A). When SEY6210 lysates, containing the wild-type VPS34 gene, were used as the template, the predicted 900-bp PCR product was observed (Fig. 5B). The heterozygous diploid, PHY120 (VPS34/vps34Al::TRP1), produced the expected doublet of 900 and 1,100 bp (Fig. 5B). Genomic DNA from four haploid progeny of a single PHY120 meiosis were also analyzed, and the results obtained are consistent with the genetic analysis of these strains (Fig. 5B). Further confirmation of the identity of the VPS34 allele(s) present was obtained by restriction of the PCR products with either BamHI or HindIII (Fig. 5A). The restriction enzyme BamHI specifically cut the 900-bp PCR product of the wild-type gene into 600 - and 300 -bp fragments and did not digest the products from the disruption allele (data not shown). Conversely, HindIII restriction resulted in the production of a 600 - and a 500 -bp fragment from the 1,100 -bp disruption allele product without affecting the 900-bp fragment (data not shown). Therefore, this PCR technique allows for a rapid (less than $6 \mathrm{~h}$ ), nonisotopic, and precise analysis of the genomic DNA at the VPS34 locus.

As expected, the $\Delta v p s 34$ cells exhibited an extreme vacuolar protein sorting defect, mislocalizing $>95 \%$ of its CPY to the cell surface in a p2 precursor form (Fig. 2). The presence of the wild-type VPS34 gene on a CEN-containing plasmid completely corrected this sorting defect (Fig. 2). As with the original temperature-sensitive alleles (36), the CPY 
A

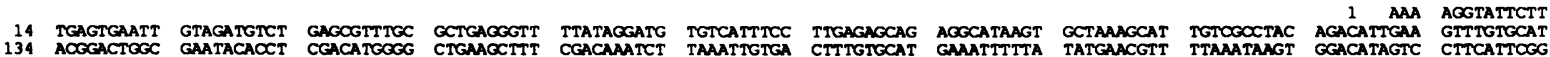

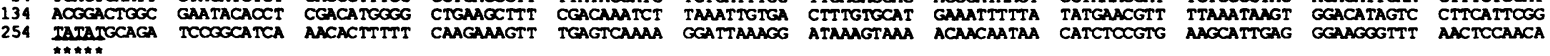

374 ATG TCA CTG AAC AAC ATA ACA TTC TGT GTC TCA CAG GAT CTG GAT GTT COC CTG AA GTG AAA ATC AAG TCA TTG GAA GGA CAT AAG CCA CTG TTG AAG CCA TCT CAA 482 AAA ATC CTG AAC CCT GAA TTA ATG CTG ATA GOG TA AAT GTA TTC 482 AAA ATC CTG AAC CCT GAA TTA ATG CTG ATA GOG TCA AAT GTA TTC CCT TCT AGT GAT CTA ATT GTA TOC TTA CAG GTA TTT GAT AAA GAG AGA AAC AGA AAT TTA ACT
37 Lys Ile Leu Asn Pro Glu Leu Mot Lou Ile Gly Ser Asn Val Phe Pro Sor Ser Asp Lou Ile Val Ser Leu Gln Val Phe Asp Lys Glu Arg Asn Arg Asn Leu Thr

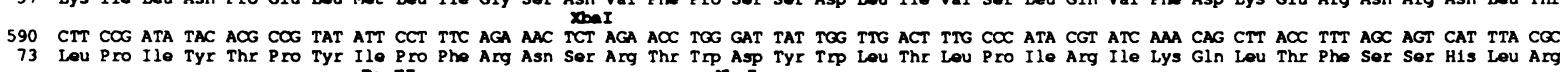
698 ATT ATT TTG TOG GAA TAC AAT GGA TOC AAG CAA ATT COC TTT TTC AAT CTA GAA ACG ACC ATC ITT AAC TTA AAA GAC TGT ACT TTA AAA AGA GOG TTT GAA TOC TTA 109 Ile Ile lou Trp Glu Tyr Asn Gly Ser Lys Gln Ile Pro Pho Phe Asn Leu Glu Thr Ser Ilo phe Asn Lou Lys Asp Cys Thr Lou Lys Arg Gly Phe Glu Ser Leu

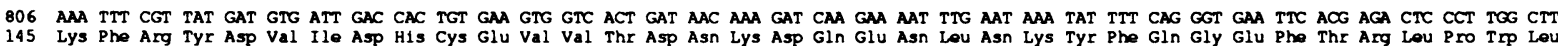
914 GAC GAA ATC ACT ATA A@C AAA TTA AGG AAA CAA COG GAA AAT AGG ACT TOG CCT CAG GOC ACC TIT GTC TTA AAC TTA GAA TTT CCA ATG TTA GAG CTT CCT GTT GTC

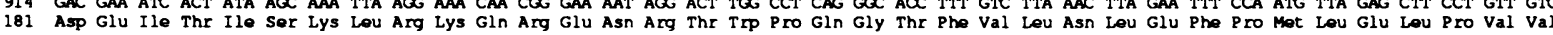

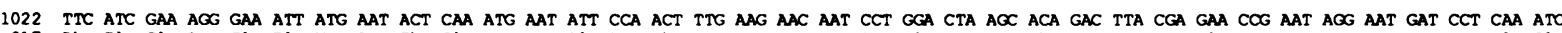
217 Phe Ile Glu Arg Glu Ile Met Asn Thr Gln Mot Asn Ile Pro Thr Lou Lys Asn Asn Pro Gly Lou Ser Thr Asp Lou Arg Glu Pro Asn Arg Asn Asp Pro Gln Ile 1130 AAA ATT TCT TTG GOG GAC AAA TAT CAC TOC ACA TTG AAG TTT TAC GAT CCT GAC CAA CCA AAC AAT GAT CCA ATA GAG GAA AAG TAT AGG AGA TTG GAA AGA GCA TCT 1238 AAA AAT GCA AAC TTG GAC AAG CAA GTG AAG COG GAC ATT AAA AAG AGG GAC TAC TTG AAT AAA ATC ATC AAC TAC COC CCT GOC ACT AAA TTA ACA GCA CAT GAA AAG 289 Lys Asn Ala Asn Leu Asp lys Gln Val Lys Pro Asp Ile Lys lys Arg Asp tyr Lou Asn Lys Ile Ile Asn tyr pro pro Gly thr Lys Leu Thr Ala H1s Glu Lys 1346 GGT TCA ATA TOG AAA TAT AGG TAT TAT TTG ATG AAC AAT AAA AAA GCT CTT ACA AAG TTA TTA CAG AGT ACA AAT TTG AGA GAA GAA TOG GAA AGA GTA GAG GTT TTA

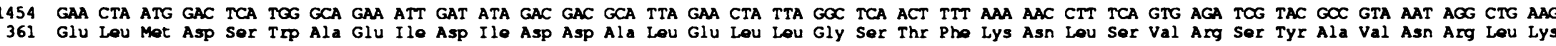
1562 AAG GCA TCA GAC AAG GAG CTG GAA TTG TAC TTA TTA CAG TTG GTA GAA GCT GTC TGT TTT GAG AAC CTG TOC ACT TTT TOC GAC AAA TCT AAC AGT GAA TTC ACT ATT 397 Lys Ala Ser Asp Lys Glu Lou Glu Lou Tyr Lou Lou Gln Lou Val Glu Ala Val Cys Pho Glu Asn Lou Ser Thr Phe Sor Asp Lys Ser Asn Ser Glu Pho Thr Ile 1670 GTG GAT GOC GTA TCT TOG CAA AAG CTT TOG GGT GAT TCT ATG TTA CTA TCT ACA TOG CAT GOC AAC CAA AAA TTA TTA AAG TOC ATC TOG AGT GAA TOG GAA ACT TOC
433 Val ASP Ala Val Ser Ser Gln Lys Leu Ser Gly Asp Ser Met Leu Leu Ser Thr Ser His Ala Asn Gln Lys Leu Leu Lys Ser Ile Ser Ser Glu Ser Glu Thr Se 1778 GOG ACA GAA TCG CTA CCA ATC GTC ATT TCT COC TTG GCT GAG TTT TTG ATT AGG AGA GCA CTG GTC AAC CCA AGG TTA GCA AGT TTT TTC TAT TOG TAT TTA AAG TCC

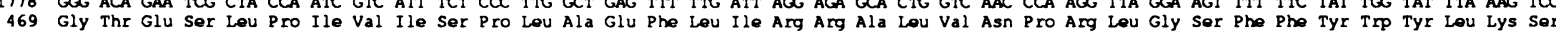
1886 GAG TCT GAG GAC AAG CCA TAT TTA GAC CAG ATT TTA AGT TCC TTT TOG AGT AGA CTG GAT AAA AAA TCT COG AAT ATA CTG AAC GAT CAA GTC AGG CTA ATA AAT GTG

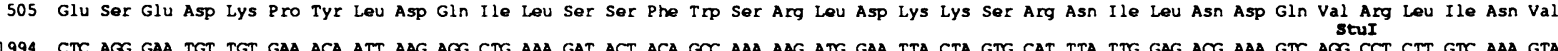

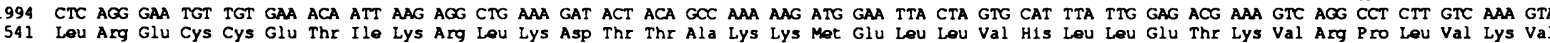
2102 CGA CCA ATT GCT TTA CCA CTA GAC CCT GAT GTS TTG ATA TœC GAC GTT TGT CCT GAA ACT TCG AAG GTA tTT AAA ACC TCT TTA TCG CCA CTA AAA ATA ACA TTC AAA 577 Arg pro Ile ala lou pro leu Asp pro asp val leu Ile Cys asp Val Cys pro glu thr Ser lys val phe lys Ser Ser leu Ser pro leu lys Ile thr phe lys 2210 ACG AOC TTA AAC CAA CCA TAT CAC TTA ATG TTT AAG GTT GOC GAT GAT TTG AGA CAA GAT CAA CTG GTA GTA CAG ATC ATA AGT TTA ATG AAT GAG TTA TTA AAA AAT 2318 GAA AAC GTG GAC TTG AAA TTG ACA CCA TAC AAA ATT TTG GCA ACA GGA CCA CAA GAA GGT GOC ATT GAA TTT ATC CCT AAT GAC ACA TTA GCT ACC ATA CTA AGC AAA
649 Glu Asn Val Asp Leu Lys Lou Thr Pro Tyr Lys Ile Lou Ala Thr Gly Pro Gln Glu Gly Ala Ilo Glu Pho Ilo Pro Asn Asp Thr LOu Ala Ser Ile Lou Ser Lys 2426 TAT CAC GGT ATT CTT GOC TAC CTT AAA CTC CAC TAT CCT GAT GAG AAC GCG ACA TTA GOC GTA CAA GOC TOG GTT TTA GAT AAT TTT GTC AAA TCT TGT GCT GOC TAT 685 Tyr H1s Gly Ile Lou Gly tyr Leu Lys Leu h1s tyr pro Asp glu Asn Ala thr Leu Gly val Gin Gly trp val Leu Asp Asn phe Val Lys Ser Cys Ala Gly tyr 2534 TGT GTT ATT ACA TAC ATC TTA GGT GTC GOC GAT AOG CAT TTA GAC AAC TTA CTA GTC ACG CCA GAT GOG CAC TTT TTT CAC GCA GAC TTT GGT TAT ATC TTG GGT CAC 2642 GAC CCC AAA CCT TTT CCG CCA TTA ATG AAA TTG CCC CCT CAA ATT ATA GAG GCG TTT GOG GGT GCA GAA TCA TCA AAT TAT GAT AAA TTT COC AGC TAC TGT TTT GTC

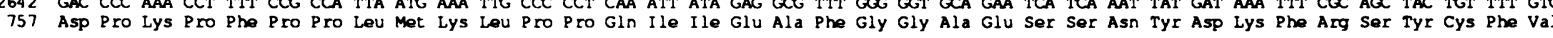
2750 GCA TAT TCG ATT TTA AGA AGG AAT GCA GOC TTA ATC TTA AAC CTG TTT GAA TTA ATG AAG ACT TCG AAC ATA CCT GAT ATC AGA ATA GAT COC AAT GGT GCT ATA TTA

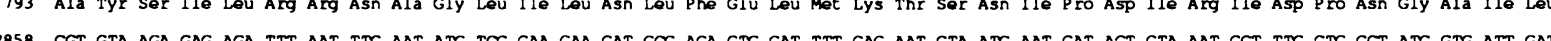

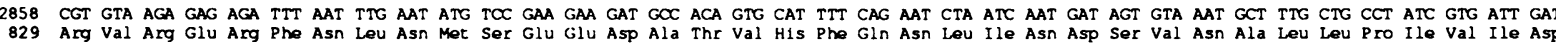
2966 CAT TTA CAT AAT CTG GCA CAA TAC TGG OGG ACC TGA 3001 865 H1s Leu H1s Asn Leu Ala Gln Tyr TrP Arg Thr End
875

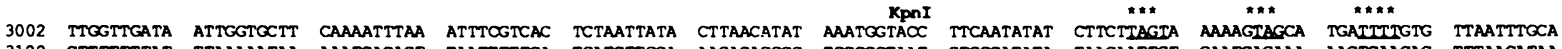

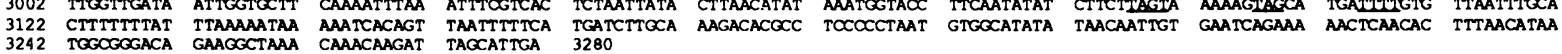

B

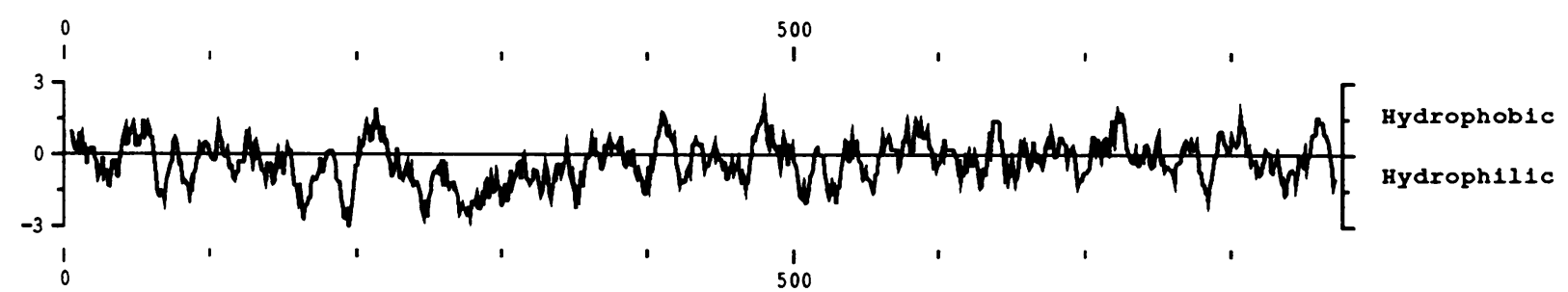

FIG. 4. (A) Nucleotide sequence of the VPS34 locus. The DNA sequence of the VPS34 coding strand and the predicted primary sequence of its product are shown. The positions of important restriction enzyme sites are indicated above their respective recognition sequences. Potential transcriptional initiation and termination signals are indicated with asterisks. (B) Hydropathy analysis of Vps34p. The predicted amino acid sequence of the VPS34 gene product was subjected to a hydropathy analysis by the method of Kyte and Doolittle (23). A scanning window of 11 amino acids was used. Hydrophobic values lie above the horizontal axis; hydrophilic values lie below. The amino acids are numbered along the horizontal axis. 


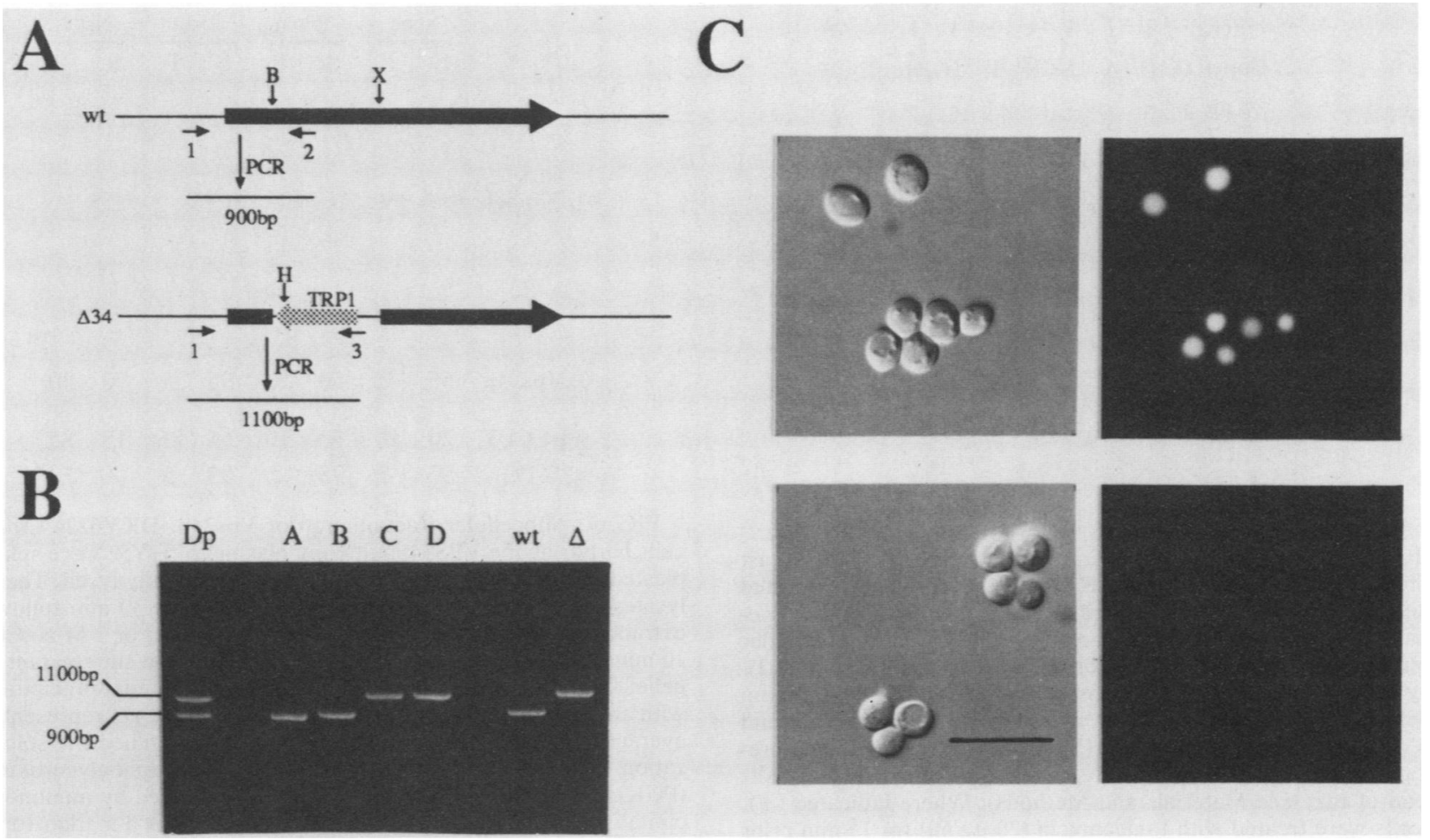

FIG. 5. (A) Construction of a gene disruption at the VPS34 locus and verification of the resulting genomic structures. The 1.0-kb BamHI-Xhol fragment of the VPS34 gene was replaced by the yeast TRPI gene as described in Materials and Methods. The genomic structure at the VPS34 genetic locus was analyzed by PCR DNA amplification. Three 25 -mer primers were added to the genomic DNA template, and 30 cycles of amplification with TaqI polymerase were performed. If the wild-type (wt) VPS34 gene is present, an amplification product of $\sim 900$

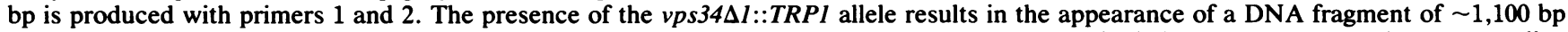
from primers 1 and 3. The heavy black arrows indicate VPS34 coding sequence, and the large stippled arrow represents the TRPI coding region. (B) Analysis of the PCR products by agarose gel electrophoresis. The PCR products were run out on $1.2 \%$ agarose gels, stained with ethidium bromide, and then photographed. The genomic DNA analyzed was obtained from yeast as follows: Dp indicates the diploid strain PHY120; A, B, C, and D indicate the four haploid progeny from a single PHY120 meiosis; and wt refers to SEY6210. The $\Delta$ reaction mix contained $\sim 0.5 \mathrm{ng}$ of pPHY38 plasmid DNA. Genetic analysis of the PHY120 progeny indicated that A and B were wild type at the VPS34 locus and $\mathrm{C}$ and $\mathrm{D}$ were mutant (growth at $37^{\circ} \mathrm{C}$ and CPY localization were assessed; data not shown). The positions of the 900 - and 1,100 -bp products are indicated. (C) Analysis by Nomarski optics and epifluorescence. No intracellular ade2 fluorescence is detected within PHY103 cells (vps34 $1:: T R P 1$ ade2). Yeast cells were grown to stationary phase in YPD medium, mounted for microscopy, and then examined by either Nomarski interference optics (left) or epifluorescence (right). The top panels show SEY6210 (VPS34) cells, and the bottom panels show PHY103 (vps34 $1:: T R P 1)$. Bar, $20 \mu \mathrm{m}$.

missorting phenotype was equivalent at both the permissive and nonpermissive growth temperatures in the $\Delta v p s 34$ strains (data not shown). As well, $\Delta v p s 34$ yeast cells were observed to be osmotically sensitive, as illustrated by their lack of growth on medium supplemented with $1.5 \mathrm{M} \mathrm{NaCl}$ (Fig. 1).

The disruption allele of VPS34 resulted in one additional phenotype not seen with any other vps34 allele. Normally, ade 2 yeast colonies turn red on adenine-limiting media. This coloring is apparently due to the accumulation of a naturally fluorescent metabolic intermediate of adenine biosynthesis in the vacuolar compartment $(17,47,53)$. Therefore, the vacuoles of ade2 yeast cells are fluorescent and easily visualized by light microscopy (53). When $\Delta v p s 34$ ade2 double mutants were placed on adenine-limiting medium, the colonies remained white (as do $A D E 2$ colonies). By introducing the wild-type VPS 34 gene back into these mutants, they regained the red ade 2 phenotype, demonstrating that the ade2-white phenotype was a direct consequence of the $v p s 34 \Delta 1:: T R P 1$ allele. This defect was also apparent at the cellular level. Whereas the vacuoles of SEY6211 (ade2 VPS34) were strongly fluorescent, $\Delta v p s 34$ ade2 cells exhibited no significant intracellular fluorescence (Fig. 5C). A similar ade2-white phenotype was observed with the class C vps mutants (3). These mutants apparently lack a normal vacuolar compartment, and the absence of ade 2 fluorescence may be due to the lack of a compartment in which to sequester this metabolic intermediate of adenine biosynthesis. In contrast, $\Delta v p s 34$ cells do possess a detectable vacuolelike intracellular organelle (see Nomarski photographs, Fig. 5C). These organelles, like wild-type vacuoles, are able to accumulate fluorescent dyes specific for the vacuole, such as FITC and CDCFDA (see below). It is interesting that the two spontaneously isolated temperature-sensitive alleles of VPS34 result in an intermediate ade2 phenotype (pink), suggesting that these two alleles retain residual VPS34 gene function.

Diploid strains homozygous for the vps34Al::TRPI allele sporulated with a much lower efficiency than did wild-type diploids or those that were heterozygous at the VPS34 locus (data not shown). A similar sporulation-deficient phenotype has been observed with pep4/pep 4 diploid strains $(50,57)$, suggesting that the sporulation defects of $\Delta v p s 34$ diploids may be due to the decreased levels of PrA enzymatic activity associated with these mutants (data not shown; 36).

Identification and characterization of Vps34p. To charac- 


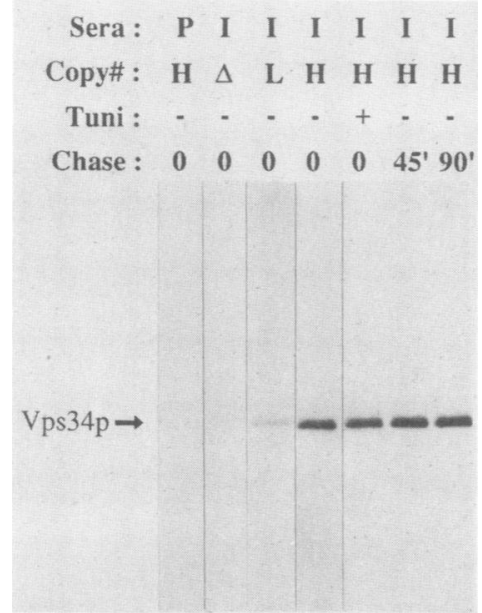

FIG. 6. Identification and characterization of Vps34p. Yeast strains were labeled with Tran ${ }^{35} \mathrm{~S}$ label in YNB-glucose minimal medium for $30 \mathrm{~min}$ at $30^{\circ} \mathrm{C}$. The cells were broken, and immunoprecipitations were performed from the clarified cell lysates with either the preimmune control serum (P) or the Vps34p immune serum (I). Copy number refers to the gene dosage of VPS34; $\triangle$ is PHY102 (no copies), L is SEY6210 (one copy), and H is SEY6210 with plasmid pPHY52 (multiple copies). The PHY102 and SEY6210 immunoprecipitations were performed from eight $\mathrm{OD}_{600}$ equivalents of cells instead of two (see Materials and Methods). Where indicated $(+)$, the cells were treated with tunicamycin $(20 \mu \mathrm{g} / \mathrm{ml})$ for $15 \mathrm{~min}$ prior to labeling. The labeled cultures were chased with cold methionine and cysteine (final concentration, $2 \mathrm{mM}$ ) for the indicated times. The position of $\mathrm{Vps} 34 \mathrm{p}$ is indicated $(95,000 \mathrm{Da})$.

terize the VPS34 gene product, we prepared polyclonal antisera against a TrpE-Vps34 fusion protein isolated from $E$. coli (see Materials and Methods). This fusion protein consisted of amino acids 125 to 462 of Vps34p fused in frame to the $C$ terminus of the $E$. coli trpE protein. Upon induction with indoleacrylic acid, an artificial inducer of the trp operon, $E$. coli cells carrying this trpE-VPS34 fusion gene produced a novel protein of $74-\mathrm{kDa}$ at a relatively high level ( $\sim 10 \%$ of total cell protein). This hybrid protein was purified and used to immunize rabbits. The resulting polyclonal antiserum was used in quantitative immunoprecipitations from radiolabeled yeast extracts. This antiserum detected a unique polypeptide of an apparent molecular weight of $\sim 95,000$ from wild-type yeast cells (Fig. 6). This relatively rare yeast protein was not immunoprecipitated by the preimmune control serum and was not detected in $\Delta v p s 34$ cell extracts (Fig. 6). In addition the presence of a multicopy VPS34 plasmid resulted in an approximately 30 to 50-fold increase in the level of this $95-\mathrm{kDa}$ polypeptide (Fig. 6). These data indicate that the polyclonal antiserum specifically recognizes the protein product of the VPS34 gene. Densitometric analysis of the levels of Vps34p relative to CPY $(\sim 0.1 \%$ of total cell protein) suggested that Vps34p comprises $<0.01 \%$ of total cell protein in logarithmically growing yeast cultures. It is interesting that the overproduction of Vps34p did not result in a vacuolar protein sorting defect (Fig. 3).

The predicted sequence of $\mathrm{Vps} 34 \mathrm{p}$ indicates that this protein contains 10 potential sites for $\mathrm{N}$-linked glycosyl modification. However, the apparent absence of any potential N-terminal signal sequence, or other membrane-spanning domains, suggests that this protein does not enter the secretory pathway. To directly test this prediction, we treated yeast cells with the drug tunicamycin, a potent

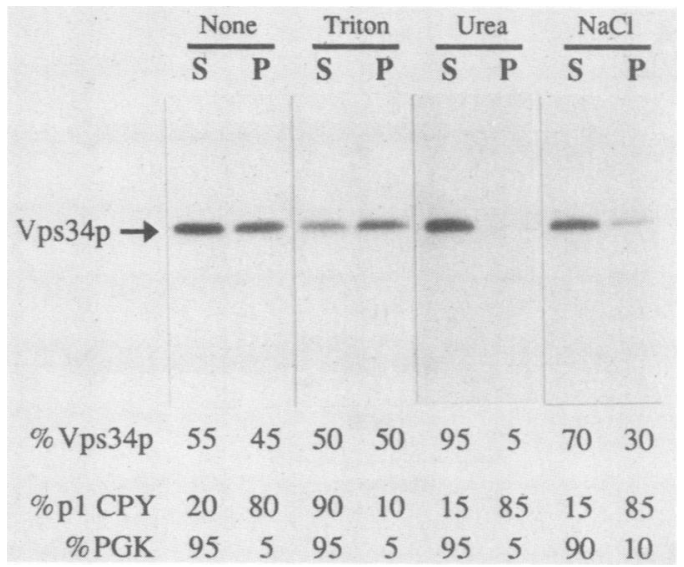

FIG. 7. Subcellular fractionation of Vps34p. DKY6224 ( cells harboring the VPS34 multicopy plasmid pPHY 52 were spheroplasted, labeled with Tran ${ }^{35} \mathrm{~S}$ label, and osmotically lysed. The cell lysates were then centrifuged at $100,000 \times g$ for 30 min following extraction with either $1 \%$ Triton X-100, $2 \mathrm{M}$ urea, or $1 \mathrm{M} \mathrm{NaCl}$ for $10 \mathrm{~min}$ at $0^{\circ} \mathrm{C}$. The relative levels of $\mathrm{Vps} 34 \mathrm{p}$ in the supernatant and pellet fractions were assessed by quantitative immunoprecipitation with antiserum to Vps34p. The values beneath the gel represent the averages of three different experiments that examined the solubilization properties of Vps34p, p1 CPY, and phosphoglycerokinase (PGK); the relative levels of each were determined by immunoprecipitation with the appropriate antisera. p1 CPY is a marker for the ER and early Golgi compartments, and phosphoglycerokinase is a cytoplasmic protein.

inhibitor of $\mathrm{N}$-linked glycosylation, prior to labeling and immunoprecipitation. The Vps34p detected from tunicamycin-treated cells was indistinguishable from the wild-type protein on SDS-polyacrylamide gels, suggesting the absence of asparagine-linked oligosaccharide modification (Fig. 6). Pulse-chase experiments indicated that Vps34p was a relatively stable protein species, with a half-life of at least $90 \mathrm{~min}$ (Fig. 6). Therefore, Vps34p is a relatively rare, unglycosylated protein of approximately 95,000 $\mathrm{Da}$ in molecular mass.

Subcellular fractionation of Vps34p suggests an association with a multiprotein complex. The nucleotide sequence data indicated that Vps34p is a relatively hydrophilic protein lacking any potential transmembrane domains and therefore might have a cytoplasmic localization. We used differential centrifugation techniques to directly analyze the intracellular location and associations of Vps34p. Yeast spheroplasts were labeled for $30 \mathrm{~min}$ with $\left[{ }^{35} \mathrm{~S}\right]$ methionine and $\left[{ }^{35} \mathrm{~S}\right]$ cysteine, osmotically lysed, and subjected to differential centrifugations prior to quantitative immunoprecipitation with antiserum to Vps34p. The osmotic lysis conditions were chosen so that the integrity of specific internal organelles, including the ER and Golgi compartments, was not disturbed. Approximately $80 \%$ of the p1 and p2 CPY, markers for the ER and Golgi compartments $(12,48)$, was detected in a $13,000 \times g$ pellet fraction (Fig. $7 ; 10$ ). In addition, more than $90 \%$ of the mature CPY was released into a soluble fraction, indicating that the vacuolar compartment was disrupted by this lysis procedure (data not shown; 10).

The lysates of DKY6224 cells harboring the multicopy VPS34 plasmid pPHY52 were centrifuged at $100,000 \times g$ for $30 \mathrm{~min}$, and the distribution of $\mathrm{Vps} 34 \mathrm{p}$ between the supernatant and pellet fractions was assessed. Approximately $50 \%$ of the Vps34p was present in the pellet fraction (Fig. 7). The nature of the association of Vps34p with this particulate fraction was analyzed by using several different extraction 
procedures. Following osmotic lysis, the cell lysates were incubated with either $1 \%$ Triton $\mathrm{X}-100,2 \mathrm{M}$ urea, or $1 \mathrm{M}$ $\mathrm{NaCl}$ for $10 \mathrm{~min}$ at $4^{\circ} \mathrm{C}$. The lysates were then centrifuged at $100,000 \times g$ for $30 \mathrm{~min}$, and the supernatant and pellet fractions were analyzed for the presence of Vps34p by immunoprecipitation. Extraction with $1 \%$ Triton X-100 did not significantly alter the distribution of $\mathrm{Vps} 34 \mathrm{p}$ between the two fractions; $\sim 50 \%$ of the Vps $34 p$ was still present in the pellet fraction (Fig. 7). This Triton X-100 treatment was sufficient to solubilize p1 CPY (Fig. 7) and the integral vacuolar membrane protein, alkaline phosphatase (data not shown; 20). Treatment with $2 \mathrm{M}$ urea readily solubilized Vps34p from the particulate fraction (Fig. 7), suggesting that Vps34p is associated with this pelletable structure through protein-protein interactions. This urea extraction failed to solubilize either p1 CPY (Fig. 7) or alkaline phosphatase (data not shown). The partial solubilization by a $1 \mathrm{M} \mathrm{NaCl}$ extraction further suggests that the presence of $\mathrm{Vps} 34 \mathrm{p}$ in this complex is mediated by ionic interactions. We have observed that $\sim 30 \%$ of this particulate Vps $34 p$ is present in a $13,000 \times g$ lower-speed pellet. The presence of $\mathrm{Vps} 34 \mathrm{p}$ in the particulate fraction was not the result of its overexpression in these experiments, as $\sim 40$ to $50 \%$ of Vps $34 p$ was detected in $100,000 \times g$ pellet of DKY6224 cells expressing wild-type levels of this protein (data not shown). This particulate Vps34p was also solubilized by an extraction with $2 \mathrm{M}$ urea but not with $1 \%$ Triton $X-100$. Indirect immunofluorescence experiments were performed with the Vps34p-specific antiserum to localize the Vps34p within the yeast cell. In wild-type cells, we observed a weak punctate staining evenly distributed throughout the entire cytoplasm; this signal was absent in $\Delta v p s 34$ cells (data not shown).

Vacuole formation is delayed in $\Delta v p s 34$ cells. A large vacuolelike organelle was detected within $\Delta v p s 34$ cells by Nomarski optics, but this compartment did not accumulate the endogenous ade2 fluorophore (Fig. 5C). To determine the nature of this compartment, we labeled PHY103 yeast cells ( $v p s 34 \Delta 1:: T R P 1$ ade2) with two fluorescent dyes, FITC and CDCFDA, which have been shown to accumulate specifically within the vacuoles of wild-type yeast cells (3, $34,53)$. The intracellular compartments within $\Delta v p s 34$ cells were specifically stained by both of these two fluorophores, indicating that these structures are similar to wild-type vacuoles (Fig. 8A and data not shown). However, within a population, the vacuolar compartment visualized in $\Delta v p s 34$ strains was a much more heterogeneous structure than that observed in wild-type cells. Generally one to three large FITC-staining compartments are detected within wild-type cells $(3,33,53)$. In $\Delta v p s 34$ cells, the size of the FITC-staining compartment varied greatly, with approximately 50 to $60 \%$ of the population resembling wild-type cells (data not shown). Approximately 5 to $10 \%$ of the $\Delta v p s 34$ cells in a logarithmically growing culture did not exhibit any FITC fluorescence, a phenotype similar to that observed with the class C vps mutants (3). The remaining $\sim 30 \%$ of the $\Delta v p s 34$ cells exhibited an intermediate morphology in which the cells possessed multiple small staining compartments.

The most striking observation made with the $\Delta v p s 34$ strains was that in general, no vacuolar compartment was observed in newly forming cells. In wild-type cells, a vacuole is detected in the newly forming bud when it is only a fraction of the size of the mother cell (53). In $\Delta v p s 34$ cells, no vacuole, or only a very small compartment, was observed in the newly forming bud by both FITC fluorescence and Nomarski microscopy (Fig. 8A). A total of 45 budding cells were observed at a time when the bud was greater than $50 \%$
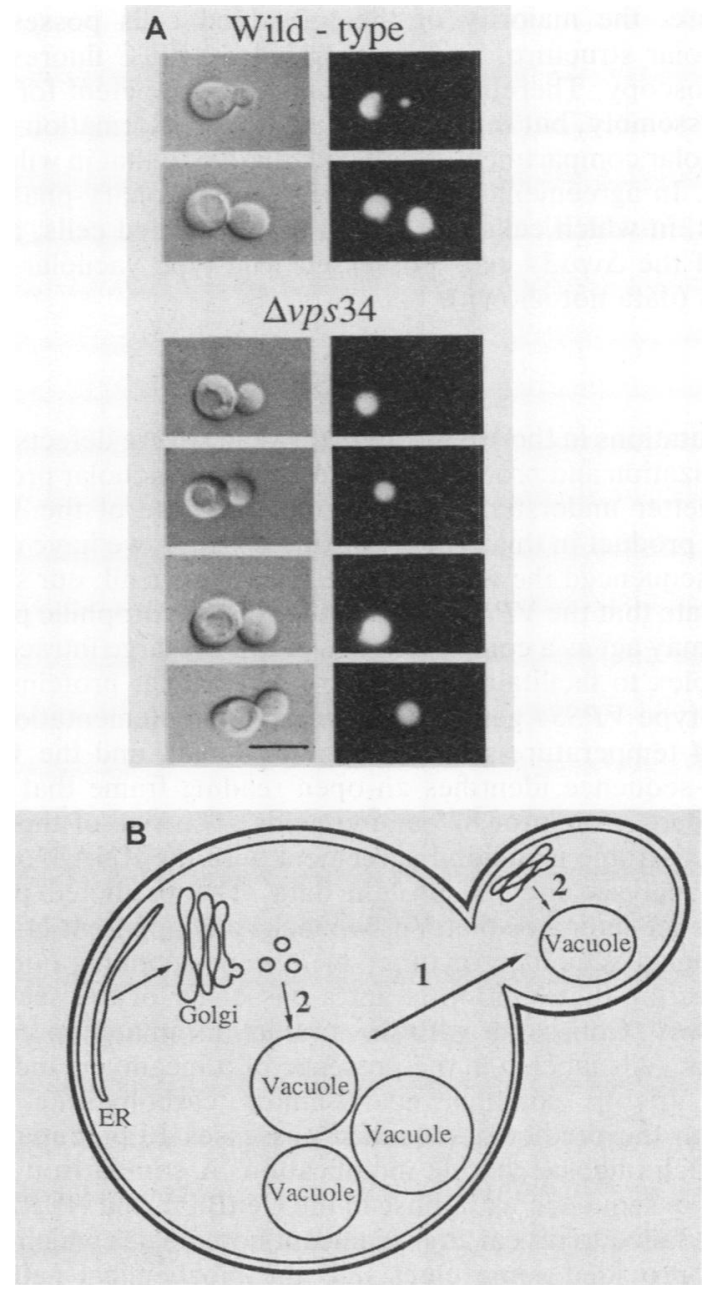

FIG. 8. (A) Delay of vacuole formation in PHY103 cells (vps34 $1::$ TRPl). Yeast cells were grown in YPD medium to early log phase and were stained with the fluorescent dye FITC for $15 \mathrm{~min}$ at room temperature. The cells were then mounted for microscopy and examined by either Nomarski interference optics (left) or epifluorescence (right). The top two rows show SEY6210 dividing pairs (wild type), and the bottom four show PHY103 pairs ( $\Delta v p s 34)$. No FITC staining is detected in the buds of PHY103 cells. Bar, 10 $\mu \mathrm{m}$. (B) Vacuolar assembly in yeast cells. A simple model depicting two intracellular pathways contributing to vacuolar growth is shown. Pathway 1 (inheritance pathway) represents the contribution of the mother cell vacuole to the contents of the bud vacuole. Pathway 2 (biosynthetic pathway) depicts the transport of newly synthesized vacuolar constituents from the Golgi complex to the vacuolar compartment(s). The contribution of endocytosis to vacuolar content and the potential delivery of vacuolar constituents from the mother cell Golgi complex to the bud vacuole are not shown. See text for further discussion.

the size of the mother cell. In 38 cases no FITC staining was observed in the daughter bud, and in the 7 remaining dividing pairs only a very small vacuole was detected in the bud. In all cases but one, the mother cell possessed a normal FITC-staining compartment (Fig. 8A). At a similar point in the cell cycle, 28 of 30 wild-type buds examined were observed to possess a relatively large vacuolar compartment (Fig. 8A; 53). Identical results were obtained by staining the dividing yeast cells with a second fluorescent dye, CDCFDA (data not shown). In a logarithmically growing $\Delta v p s 34$ yeast 
culture, the majority of the unbudded cells possessed a vacuolar structure, as demonstrated by FITC fluorescence microscopy. Therefore, these cells are competent for vacuole assembly, but the data indicate that the formation of this vacuolar compartment is delayed relative to that in wild-type cells. In agreement with this view, in stationary-phase cultures, in which cells arrest in $G_{1}$ as unbudded cells, almost all of the $\Delta v p s 34$ cells possessed wild-type vacuolar structures (data not shown).

\section{DISCUSSION}

Mutations in the VPS34 gene result in severe defects in the localization and processing of a number of vacuolar proteins. To better understand the physiological role of the VPS34 gene product in this protein sorting process, we have cloned and sequenced the wild-type VPS34 gene. In all, our studies indicate that the VPS34 gene product is a hydrophilic protein that may act as a component of a relatively large intracellular complex to facilitate the delivery of vacuolar proteins. The wild-type VPS34 gene was cloned by complementation of a vps34 temperature-sensitive growth defect, and the VPS34 gene sequence identifies an open reading frame that could encode a protein of 875 amino acids. The size of this open reading frame is in good agreement with the RNA Northern blot analysis and the protein data. The predicted protein sequence indicates that Vps34p lacks any apparent $\mathrm{N}$-terminal signal sequence or other membrane-spanning domains, suggesting that $\mathrm{Vps} 34 \mathrm{p}$ is not a passenger of the secretory pathway. Consistent with this prediction, immunoprecipitation of cells labeled in the presence of tunicamycin indicates that Vps34p contains no $\mathrm{N}$-linked carbohydrate, even though the predicted sequence possesses 10 potential sites for such oligosaccharide modification. A comparison of the Vps34p sequence with those in the GenBank and NBRF data bases failed to reveal any significant homologies which might have provided some clues into the biochemical nature of Vps34p function.

Some insight into the possible function of Vps34p may be provided by subcellular fractionation studies which indicate that approximately $50 \%$ of the radiolabeled Vps34p associates with a particulate fraction of yeast cells. The solubility properties of this particulate Vps $34 p$ suggest that proteinprotein interactions are responsible for the presence of Vps34p in the pellet fraction. The failure of Triton X-100 to solubilize Vps $34 p$ from this structure further suggests that this protein is not simply associating as a peripheral protein with a specific intracellular membrane. Instead, the fractionation data are consistent with Vps34p being a component of a relatively large multiprotein complex. This complex is presumably functioning to facilitate a specific step(s) in the vacuolar protein sorting process. Since only about $50 \%$ of the Vps34p was detected within the pellet fraction, Vps34p may exist in, and perhaps cycle between, two separate intracellular pools. One interesting possibility, suggested by the Triton X-100 fractionation data, is that Vps34p is associated with the cytoskeletal network of yeast cells. In higher eucaryotic cells, the cytoskeleton has been operationally defined as the interconnected proteins that remain following an extraction of the cells with nonionic detergents such as Triton X-100 (5). Further biochemical studies are necessary to determine the precise nature of the association of Vps34p with this particulate fraction. We have initiated an analysis of temperature-resistant suppressors of $v p s 34(\mathrm{Ts})$ mutants in an attempt to identify the specific cellular components which interact with the Vps34p in vivo. The genetic analysis, in combination with the biochemical studies, should lead to a better understanding of the role of $\mathrm{Vps} 34 \mathrm{p}$ in the delivery of vacuolar proteins.

We constructed a gene disruption of VPS34 to assess the phenotypic consequences of a null allele of this locus. The structure of the disrupted allele in the genomic DNA was verified by a rapid, nonisotopic PCR analysis (Fig. 5A and B). Haploid yeast strains possessing the vps34 $1:: T R P 1$ allele produced no detectable Vps34p and exhibited a severe temperature-sensitive growth defect. Therefore, the VPS34 gene appears to be essential for vegetative growth only at elevated growth temperatures. To our knowledge, the observation of a null allele exhibiting such a conditionally lethal growth phenotype has been made only rarely in the literature. In $S$. cerevisiae, disruptions of two different genes, both encoding products that might interact with actin, result in conditional lethal phenotypes $(13,30)$. The biological basis for the temperature-sensitive phenotype that we observe with the vps34 null mutants is not known. The severity of the vacuolar protein sorting defect was observed to be equivalent at the permissive and nonpermissive growth temperatures, at least for vacuolar delivery of CPY. It is possible that more severe sorting defects, perhaps affecting additional proteins, become apparent at the elevated growth temperatures and result in the observed temperature-sensitive phenotype. The secretion of invertase, as well as other secreted proteins, appears to be normal at the nonpermissive growth temperature in vps34(Ts) mutants (36), suggesting that the cessation of growth is not due to a block in general protein secretion. It is possible that the vps34 sorting defects result in a decrease in specific vacuolar activities that are required for vegetative growth at this elevated temperature. The proteins responsible for these activities may themselves be mislocalized in vps 34 mutant cells. Alternatively, the cumulative stress of decreased vacuolar function plus the elevated growth temperature may, in an additive fashion, result in the observed inviability. In light of the rarity of conditionally lethal null alleles, it is interesting that a similar temperaturesensitive null phenotype has been observed for a number of VPS genes, including VPS1 (39), END1/VPS11 (9), VPS15 (P. Herman et al., submitted for publication), VPS33 (4), and VPS16 (B. Horazdovsky, unpublished observations). Interestingly, mutations in each of these genes result in defects in vacuole assembly and an extreme sensitivity to osmotic stress $(3,9)$. Altogether, these data might suggest a role for the yeast vacuole in cellular responses to situations of environmental stress, such as elevated growth temperatures or osmotic stress. In cultured mammalian cells, the rate of lysosomal degradation of certain cytoplasmic proteins has been shown to specifically increase in response to cell starvation (7). Clearly, more experimentation is necessary to define the precise role of the vacuole in these stress responses.

The majority of the vps 34 mutant cells possess a morphologically normal vacuolar structure when analyzed with the fluorescent dyes FITC and CDCFDA, both of which specifically accumulate within the vacuoles of wild-type yeast cells $(3,33,34)$. It is interesting that although vps34 mutants appear to be competent for vacuole assembly, they are grossly defective in the delivery of several vacuolar hydrolases, including CPY, PrA, and PrB (Fig. 3; 36). Several different models may be proposed to explain this apparent paradox. Multiple, possibly overlapping, pathways may exist for the delivery of vacuolar constituents from the Golgi complex. This appears to be the case for mammalian lysosomal proteins, as only a subset of all lysosomal constituents 
utilize the mannose-6-phosphate targeting system (22). A second possibility is that the VPS34 gene product acts relatively early in the vacuolar protein sorting process, perhaps in the packaging of the vacuolar proteins into their appropriate vesicular carriers. In this event, vesicular traffic to the vacuole may proceed almost normally except that the vesicles would lack much of their usual protein content. In both models, vacuole assembly could proceed in the absence of VPS34 gene function but vacuolar functions would be compromised since many vacuolar proteins would now be mislocalized.

During our analysis of the vacuolar compartment in $\Delta v p s 34$ mutants, we observed that more than $80 \%$ of the newly forming buds lacked a detectable vacuole. In contrast, a normal vacuolar structure was generally observed in the mother cell and in the majority of the unbudded cells in the $\Delta v p s 34$ population. Therefore, the inheritance and assembly of the vacuolar structure in dividing $\Delta v p s 34$ cells appear to be delayed relative to the processes in wild-type yeast cells. In wild-type cells, a vacuole is detected in the bud when it is only a fraction of the size of the mother cell (Fig. 8A; 53). Analyses of vacuole segregation during cell division have indicated that the daughter bud inherits a substantial portion of its vacuolar contents from the mother cell vacuole $(45,53$, 5,58 ; this inheritance pathway is shown as pathway 1 in Fig. $8 \mathrm{~B})$. The absence of a vacuole in the newly emerging bud in $\Delta v p s 34$ cells could reflect a defect in vacuolar inheritance. Similar defects in vacuolar segregation have been observed in two other yeast mutants, vacl (54) and vps3 (35). Complementation tests have demonstrated that the vps34, vacl, and vps3 mutations define different yeast genes $(21$; L. Weisman and W. Wickner, personal communication). At least two different models could be proposed to explain this apparent defect in vacuole segregation in $\Delta v p s 34$ cells. Vacuolar segregation and Golgi-to-vacuole protein transport may be mechanistically similar, and Vps34p may be required to execute a common event along both pathways. Alternatively, the severe missorting defects associated with vps34 mutations could result in a decrease in specific vacuolar activities that are required for vacuolar inheritance. Further genetic and biochemical studies are required to determine the precise role of $\mathrm{Vps} 34 \mathrm{p}$ in the partitioning of vacuolar contents between mother and daughter yeast cells.

We believe that the data presented here are most consistent with Vps34p being directly involved in the sorting of proteins to the yeast vacuolar compartment. In a population of vps34 cells, the majority of the cells exhibit a normal vacuole morphology, yet CPY is almost quantitatively mislocalized to the cell surface. The observation that vps34 cells are competent for vacuole assembly indicates that at least some vacuolar constituents are properly delivered to this organelle. The severe vps34 missorting defects would be expected to result in a significant decrease in a variety of normal vacuolar activities. Such a decrease in vacuolar function may be responsible for the phenotypes associated with vps34 alleles, including temperature-sensitive growth, osmosensitivity, and the vacuolar segregation defect. On the basis of our observations, we propose that Vps34p may be a component of a relatively large multiprotein structure that functions to facilitate specific steps of the vacuolar protein sorting pathway.

\section{ACKNOWLEDGMENTS}

We thank Elliot Altman, Todd Graham, and Jeff Stack for many helpful discussions and critical reading of the manuscript. John De Modena for technical assistance, Kurt Eakle for use of his sequence analysis software, Janet Shaw and Bill Wickner for communicating results prior to publication, and Cathy Blagg for expert assistance with preparation of the manuscript.

This work was supported by a Presidential Young Investigator Award from the National Science Foundation (to S.D.E.), Public Health Service grant GM-32703 from the National Institutes of Health (to S.D.E.), and a Natural Sciences and Engineering Research Council of Canada postgraduate scholarship (to P.K.H.).

\section{LITERATURE CITED}

1. Ausubel, F. M., R. Brent, R. E. Kingston, D. D. Moore, J. G. Seidman, J. A. Smith, and K. Struhl (ed.). 1987. Current protocols in molecular biology. John Wiley and Sons, Inc., New York.

2. Bankaitis, V. A., L. M. Johnson, and S. D. Emr. 1986. Isolation of yeast mutants defective in protein targeting to the vacuole. Proc. Natl. Acad. Sci. USA 83:9075-9079.

3. Banta, L. M., J. S. Robinson, D. J. Klionsky, and S. D. Emr. 1988. Organelle assembly in yeast: characterization of yeast mutants defective in vacuolar biogenesis and protein sorting. $J$. Cell Biol. 107:1369-1383.

4. Banta, L. M., T. A. Vida, P. K. Herman, and S. D. Emr. 1990. Characterization of yeast Vps33p, a protein required for vacuolar protein sorting and vacuole biogenesis. Mol. Cell. Biol. 10:4638-4649.

5. Branton, D., C. M. Cohen, and J. Tyler. 1981. Interaction of cytoskeletal proteins on the human erythrocyte membrane. Cell 24:24-32.

5a.Casadaban, M. J., and S. N. Cohen. 1980. Analysis of gene control signals by DNA fusion and cloning in E. coli. J. Mol. Biol. 138:179-207.

6. Devereux, J., P. Haeberli, and O. Smithies. 1984. A comprehensive set of sequence analysis programs for the VAX. Nucleic Acids Res. 12:387-391.

7. Dice, J. F. 1987. Molecular determinants of protein half-lives in eukaryotic cells. FASEB J. 1:349-357.

8. Dieckmann, C. L., and A. Tzagloff. 1985. Assembly of the mitochondrial membrane system. J. Biol. Chem. 260:1513-1520.

9. Dulic, V., and H. Riezman. 1989. Characterization of the END1 gene required for vacuole biogenesis and gluconeogenic growth of budding yeast. EMBO J. 8:1349-1359.

10. Eakle, K. A., M. Bernstein, and S. D. Emr. 1988. Characterization of a component of the yeast secretion machinery: identification of the SEC18 gene product. Mol. Cell. Biol. 8:4098-4109.

11. Emr, S. D., A. Vassorotti, J. Garrett, B. L. Geller, M. Takeda, and M. G. Douglas. 1986. The amino terminus of the yeast $F_{1}$-ATPase $\beta$-subunit functions as a mitochondrial import signal. J. Cell Biol. 102:523-533.

12. Franzusoff, A., and Schekman. 1989. Functional compartments of the yeast Golgi apparatus are defined by the $\sec 7$ mutation. EMBO J. 8:2695-2702.

13. Haarer, B. K., S. H. Lillie, A. E. M. Adams, V. Magdolen, W. Bandlow, and S. S. Brown. 1990. Purification of profilin from Saccharomyces cerevisiae and analysis of profilin-deficient cells. J. Cell. Biol. 110:105-114.

14. Ito, H., Y. Fukuda, K. Murata, and A. Kimura. 1983. Transformation of intact yeast cells with alkali cations. J. Bacteriol. 153:163-168.

15. Johnson, L. M., V. A. Bankaitis, and S. D. Emr. 1987. Distinct sequence determinants direct intracellular sorting and modification of a yeast vacuolar protein. Cell 48:875-885.

16. Jones, E. W. 1977. Proteinase mutants of Saccharomyces cerevisiae. Genetics 85:23-33.

17. Jones, E. W., and G. R. Fink. 1982. Regulation of amino acid and nucleotide biosynthesis in yeast, p. 181-299. In J. N. Strathern, E. W. Jones, and J. R. Broach (ed.), The molecular biology of the yeast Saccharomyces cerevisiae: metabolism and gene expression. Cold Spring Harbor Laboratory, Cold Spring Harbor, N.Y.

18. Kleid, D. G., D. Yansura, B. Small, D. Dowbenko, D. M. Moore, M. J. Grubman, P. D. McKercher, D. O. Morgan, B. H. Robertson, and H. L. Bachrach. 1981. Cloned viral protein vacine for foot-and-mouth disease. Science 214:1125-1129. 
19. Klionsky, D. J., L. M. Banta, and S. D. Emr. 1988. Intracellular sorting and processing of a yeast vacuolar hydrolase: proteinase A propeptide contains vacuolar targeting information. Mol. Cell. Biol. 8:2105-2116.

20. Klionsky, D. J., and S. D. Emr. 1989. Membrane protein sorting: biosynthesis, transport and processing of yeast vacuolar alkaline phosphatase. EMBO J. 8:2241-2250.

21. Klionsky, D. J., P. K. Herman, and S. D. Emr. 1990. The fungal vacuole: composition, function, and biogenesis. Microbiol. Rev. 54:266-292.

22. Kornfeld, S., and I. Mellman. 1989. The biogenesis of lysosomes. Annu. Rev. Cell Biol. 5:483-525.

23. Kyte, J., and R. F. Doolittle. 1982. A simple method for displaying the hydropathic character of a protein. J. Mol. Biol. 157:105-132.

24. Lipman, D., and W. Pearson. 1985. Rapid and sensitive protein similarity searches. Science 227:1435-1441.

25. Maniatis, T., E. F. Fritsch, and J. Sambrook. 1982. Molecular cloning: a laboratory manual. Cold Spring Harbor Laboratory, Cold Spring Harbor, N.Y.

26. Mann, C., and R. W. Davis. 1986. Structure and sequence of the centromeric DNA of chromosome 4 in Saccharomyces cerevisiae. Mol. Cell. Biol. 6:241-245.

27. Miller, J. 1972. Experiments in molecular genetics. Cold Spring Harbor Laboratory, Cold Spring Harbor, N.Y.

28. Novick, P., S. Ferro, and R. Schekman. 1981. Order of events in the yeast secretory pathway. Cell 25:461-469.

29. Novick, P., F. Field, and R. Schekman. 1980. Identification of 23 complementation groups required for post-transitional events in the yeast secretory pathway. Cell 21:205-215.

30. Novick, P., B. C. Osmond, and D. Botstein. 1989. Suppressors of yeast actin mutants. Genetics 121:659-674.

31. Pearson, W. R., and D. J. Lipman. 1988. Improved tools for biological sequence comparison. Proc. Natl. Acad. Sci. USA 85:2444-2448.

32. Pfeffer, S. R., and J. E. Rothman. 1987. Biosynthetic protein transport and sorting by the endoplasmic reticulum and Golgi. Annu. Rev. Biochem. 56:829-852.

33. Preston, R. A., R. Murphy, and E. W. Jones. 1987. Apparent endocytosis of fluorescein isothiocyanate-conjugated dextran by Saccharomyces cerevisiae reflects uptake of low molecular weight impurities, not dextran. J. Cell Biol. 105:1981-1987.

34. Pringle, J. R., R. A. Preston, A. E. M. Adams, T. Stearns, D. G. Drubin, B. K. Haarer, and E. W. Jones. 1989. Fluorescence microscopy methods for yeast. Methods Cell Biol. 31:357-435.

35. Raymond, C. K., P. J. O'Hara, G. Eichinger, J. H. Rothman, and T. H. Stevens. 1990 . Molecular analysis of the yeast VPS3 gene and the role of its product in vacuolar protein sorting and vacuolar segregation during the cell cycle. J. Cell Biol. 111:877892.

36. Robinson, J. S., D. J. Klionsky, L. M. Banta, and S. D. Emr. 1988. Protein sorting in Saccharomyces cerevisiae: isolation of mutants defective in the delivery and processing of multiple vacuolar hydrolases. Mol. Cell. Biol. 8:4936-4948.

37. Rose, M., P. Novick, J. Thomas, D. Botstein, and G. Fink. 1987. A Saccharomyces cerevisiae genomic plasmid bank based on centromere containing shuttle vector. Gene 60:237-244.

38. Rothman, J. H., I. Howald, and T. H. Stevens. 1989. Characterization of genes required for protein sorting and vacuolar function in the yeast Saccharomyces cerevisiae. EMBO J. 8:2057-2065.

39. Rothman, J. H., C. K. Raymond, T. Gilbert, P. J. O'Hara, and T. H. Stevens. 1990. A putative GTP binding protein homologous to interferon-inducible $\mathbf{M x}$ proteins performs an essential function in yeast protein sorting. Cell 61:1063-1074.

40. Rothman, J. H., and T. H. Stevens. 1986. Protein sorting in yeast: mutants defective in vacuole biogenesis mislocalization vacuolar proteins into the late secretory pathway. Cell 47:10411051.

41. Rothstein, R, J. 1983. One-step gene disruption in yeast. Methods Enzymol. 101:202-212.

42. Saiki, R. K., D. H. Gelfand, S. Stoffel, S. J. Scharf, R. Higuchi, G. T. Horn, K. B. Mullis, and H. A. Erlich. 1988. Primerdirected enzymatic amplification of DNA with a thermostable DNA polymerase. Science 239:487-491.

43. Saiki, R. K., S. Scharf, F. Faloona, K. B. Mullis, G. T. Horn, H. A. Erlich, and N. Arnheim. 1985. Enzymatic amplification of $\beta$-globin genomic sequences and restriction site analysis for diagnosis of sickle cell anemia. Science 230:1350-1354.

44. Sanger, F., F. Nicklen, and A. R. Coulson. 1977. DNA sequencing with chain-terminating inhibitors. Proc. Natl. Acad. Sci. USA 74:5463-5467.

45. Severs, N. J., E. G. Jordan, and D. H. Williamson. 1976. Nuclear pore absence from areas of close association between nucleus and vacuole in synchronous yeast cultures. J. Ultrastruct. 54:374-387.

46. Sherman, F., G. R. Fink, and L. W. Lawrence. 1979. Methods in yeast genetics: a laboratory manual. Cold Spring Harbor Laboratory, Cold Spring Harbor, N.Y.

47. Smirnov, M. N., V. N. Smirnov, E. I. Budowsky, S. G. IngeVechtomov, and N. G. Serebrjakov. 1967. Red pigment of adenine-deficient yeast Saccharomyces cerevisiae. Biochem. Biophys. Res. Commun. 27:299-304.

48. Stevens, T., B. Esmon, and R. Schekman. 1982. Early stages in the yeast secretory pathway are required for transport of carboxypeptidase $Y$ to the vacuole. Cell 30:439-448.

49. Struhl, K. 1987. Promoters, activator proteins, and the mechanism of transcriptional initiation in yeast. Cell 49:295-297.

50. Teichert, U., B. Mechler, H. Muller, and D. H. Wolf. 1989. Lysosomal (vacuolar) proteinases of yeast are essential catalysts for protein degradation, differentiation, and cell survival. J. Biol. Chem. 264:16037-16045.

51. Tschumper, G., and J. Carbon. 1980. Sequence of a yeast DNA fragment containing a chromosomal replicator and the TRP1 gene. Gene 10:157-166.

52. Valls, L. A., C. P. Hunter, J. H. Rothman, and T. H. Stevens. 1987. Protein sorting in yeast: the localization determinant of yeast vacuolar carboxypeptidase $\mathrm{Y}$ resides in the propeptide. Cell 48:887-897.

53. Weisman, L. S., R. Bacallao, and W. Wickner. 1987. Multiple methods of visualizing the yeast vacuole permit evaluation of its morphology and inheritance during the cell cycle. J. Cell Biol. 105:1539-1547.

54. Weisman, L. S., S. D. Emr, and W. T. Wickner. 1990. Mutants of Saccharomyces cerevisiae that block intervacuole vesicular traffic and vacuole division and segregation. Proc. Natl. Acad. Sci. USA 87:1076-1080.

55. Wiemken, A., P. Matile, and H. Moore. 1970. Vacuolar dynamics in synchronously budding yeast. Arch. Microbiol. 70:89103.

56. Zaret, K. S., and F. Sherman. 1982. DNA sequence required for efficient transcription termination in yeast. Cell 28:563-573.

57. Zubenko, G., E. Jones. 1981. Protein degradation, meiosis and sporulation in proteinase-deficient mutants of Saccharomyces cerevisiae. Genetics 97:45-64.

58. Zubenko, G. S., F. J. Park, and E. W. Jones. 1982. Genetic properties of mutations at the PEP4 locus in Saccharomyces cerevisiae. Genetics 102:679-690. 